\title{
Resurgence of Pseudoperonospora cubensis: The Causal Agent of Cucurbit Downy Mildew
}

\author{
Yigal Cohen, Kyle M. Van den Langenberg, Todd C. Wehner, Peter S. Ojiambo, Mary Hausbeck, \\ Lina M. Quesada-Ocampo, Aleš Lebeda, Helge Sierotzki, and Ulrich Gisi
}

First author: Faculty of Life Sciences, Bar-Ilan University, Ramat-Gan, 52100, Israel; second and third authors: Department of Horticultural Science, North Carolina State University, Raleigh 27695; fourth and sixth authors: Department of Plant Pathology, North Carolina State University, Raleigh 27695; fifth author: Department of Plant, Soil, and Microbial Sciences, Michigan State University, East Lansing 488241312; seventh author: Palacký University, Faculty of Science, Department of Botany, 78371 Olomouc, Czech Republic; eighth and ninth authors: Syngenta Crop Protection AG, CH-4432 Stein, Switzerland; and ninth author: Department of Environmental Sciences, Institute of Botany, University of Basel, CH-4056 Basel, Switzerland.

Accepted for publication 25 March 2015.

\begin{abstract}
Cohen, Y., Van den Langenberg, K. M., Wehner, T. C., Ojiambo, P. S., Hausbeck, M., Quesada-Ocampo, L. M., Lebeda, A., Sierotzki, H., and Gisi, U. 2015. Resurgence of Pseudoperonospora cubensis: The causal agent of cucurbit downy mildew. Phytopathology 105:998-1012.

The downy mildew pathogen, Pseudoperonospora cubensis, which infects plant species in the family Cucurbitaceae, has undergone major changes during the last decade. Disease severity and epidemics are far more destructive than previously reported, and new genotypes, races, pathotypes,

disease control through host plant resistance and fungicide applications has become more complex. This resurgence of $P$. cubensis offers challenges to scientists in many research areas including pathogen biology, epidemiology and dispersal, population structure and population genetics, host preference, host-pathogen interactions and gene expression, genetic host plant resistance, inheritance of host and fungicide resistance, and chemical disease control. This review serves to summarize the current status of this major pathogen and to guide future management and research efforts within this pathosystem.
\end{abstract} and mating types of the pathogen have been discovered in populations from around the globe as a result of the resurgence of the disease. Consequently,

\section{INTRODUCTION AND PATHOGEN BIOLOGY}

One of the plant groups with the most species used as human food is the family Cucurbitaceae. Such plants are grown around the tropics and in temperate areas, where those with edible fruits were among the earliest cultivated plants both in the Old and New World. Vegetable gardens, including melon and watermelon, constituted an integral element in food production in the old world since the fourth millenium BC (Zohary et al. 2012). Domestication of Cucurbita has occurred in southern Mexico more than 7,000 years ago (www.hort. purdue.edu). Cucumber is an important food source for more than 5,000 years (Robinson and Decker-Walters 1997). Today, cucumbers are cultivated throughout most temperate and tropical climates and are the fourth most widely grown vegetable crop behind tomato, cabbage, and onion (Tatlioglu 1993). In 2013, the U.S. farm value of cucumber production was approximately $\$ 363$ million, with approximately $3.6 \times 10^{5}$ tons produced for the fresh and pickling market (USDA, 2013). Up to $100 \%$ reduction in cucumber yield is possible when downy mildew strikes early and fungicides are not used. If fungicides are applied 1 week after symptom appearance, yield is reduced approximately 50\% (Holmes et al. 2015).

Disease cycle and purpose of study. Downy mildew is a major disease of cucurbits with a global distribution (Palti and Cohen 1980). The causal agent, Pseudoperonospora cubensis (Berk. \& Curt.) Rost. (Oomycota, Peronosporaceae), is an obligate biotrophic pathogen that infects over 40 host plant species belonging to 20 genera of the family Cucurbitaceae. Typical symptoms consist of

Corresponding author: Y. Cohen; E-mail address: yigal.cohen1@gmail.com
Additional keywords: disease outbreak, population changes. chlorotic lesions on upper leaf surfaces that can be irregular or angular depending on the affected host and in many cases, sporulation on the lower leaf surface is present (Fig. 1). Basic information on the biology, epidemiology, and control of the disease has been published in several review articles (Lebeda and Cohen 2011; Palti and Cohen 1980; Savory et al. 2011). The pathogen preferentially overwinters in areas without killing frost. In early spring, aerially dispersed sporangia land on the adaxial leaf surfaces. If free moisture is available for $\geq 2 \mathrm{~h}$, the sporangia release biflagellate zoospores that swim toward stomata where they encyst (Iwata 1949; Palti and Cohen 1980). Cystospores form a germ tube and then an appressorium for penetration. Hyphae grow into the intercellular space, colonize the mesophyll tissue, and establish intracellular haustoria for nutrient uptake (Fraymouth 1956; Voglmayr et al. 2004). It is likely these structures also deliver effector proteins to combat the host plant's defense response system (Tian et al. 2011; Whisson et al. 2007). Finally, sporangiophores emerge from stomata bearing sporangia at their tips (Fig. 2A) and are dispersed as either primary or secondary inoculum, continuing the disease cycle.

In the past decade, major changes in the population structure of $P$. cubensis have been described and new genotypes, races, pathotypes, and mating types were reported from around the globe. While the use of disease control products may enhance the build-up of fungicide-resistant populations, the mechanisms for selecting new races, pathotypes, and mating types are much less obvious. Possible mechanisms may involve cultivation of large acreages of monocultures, introduction of new cultivars, changes in climatic conditions (e.g., global warming), and the migration, mutation, and sexual recombination of the pathogen. This paper provides supporting evidence that migration and sexual recombination have had a major impact on the recent changes within the population structure of $P$. cubensis including (i) occurrence of new genotypes 
of $P$. cubensis in the Far East and Central Africa; (ii) ability of $P$. cubensis to be fruitborne, seedborne; seed-transmission can enable new genotypes to migrate through global trade of fruits and seeds to new habitats; and (iii) development of new offspring isolates with enhanced aggressiveness and expanded host range as a result of new immigrants belonging to an opposite mating type that mate with local genotypes.

Recent changes in population structure. In Israel, a new pathotype (number 6) appeared in 2002 (Cohen et al. 2003) capable of attacking Cucurbita species. A new mating type A2 appeared in 2010. In Europe, strong epidemics developed in cucumber in 1985; in 2009, new pathotypes evolved attacking Cucurbita spp. (see below). In the United States, a dramatic population change occurred in 2004 when new races attacked the long-standing source of cucumber resistance derived from PI 197087 (Holmes et al. 2006, 2015). Isolates belonging to the A2 mating type were detected for
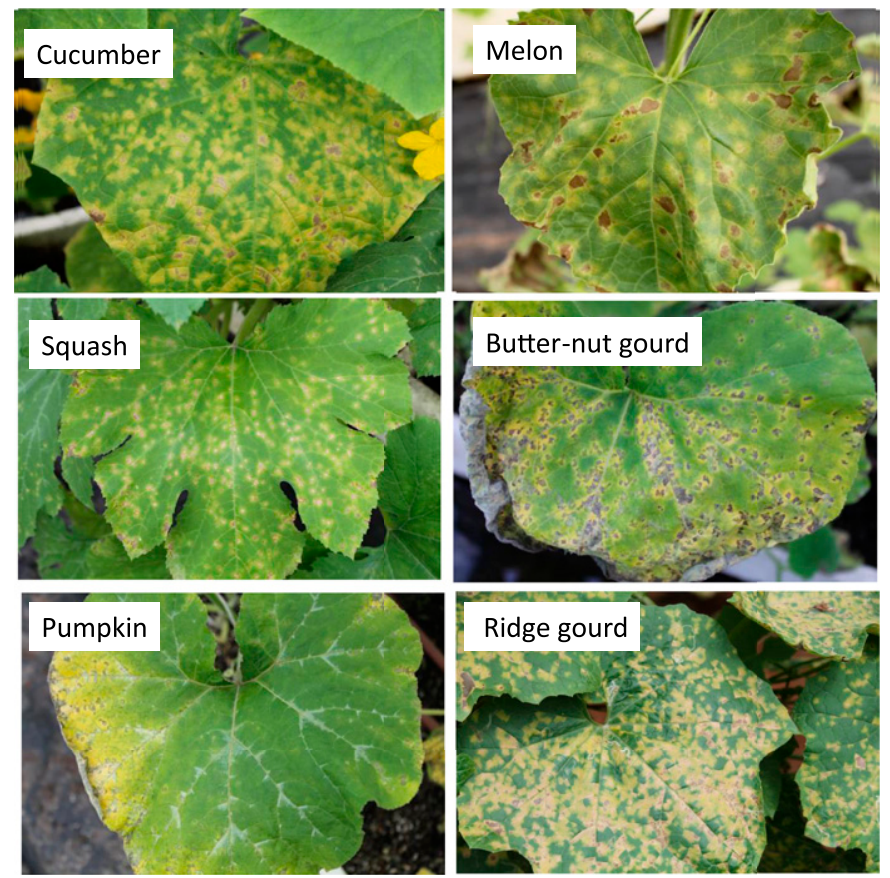

Fig. 1. Symptoms of downy mildew caused by Pseudoperonospora cubensis in six species of Cucurbitaceae. Photographs (except ridge gourd) were taken from naturally infected plants growing at Bar-Ilan University Farm, Israel on October 2014. The ridge gourd photo was taken in Bangalore area, India on September 2014. the first time in 2013 using reference isolates from Israel (Thomas et al. 2013). In China and Russia, the A2 mating type was discovered for the first time in 2013 (Cohen et al. 2013b; Y. Cohen and A. E. Rubin, unpublished data). In Vietnam, A1, A2, and homothallic isolates were reported (Y. Cohen and A. E. Rubin, unpublished data). In Kenya and Angola, the A2 mating type was discovered in 2012 and 2014, respectively (Y. Cohen, N. Bibi, and A. E. Rubin, unpublished data), and in India in September 2014 (Y. Cohen, A. E. Rubin, and D. Chandramohan, unpublished data). In September 2014, the A2 mating type was discovered for the first time in France in Sarrians (Provence-Alpes-Côte-d'Azur region, vicinity of Avignon) (Y. Cohen, M. Waldner-Zulauf, and A. E. Rubin, unpublished data), and in October 2014, in Germany in Baden-Wurttemberg (Y. Cohen, D. Hermann, and A. E. Rubin, unpublished data).

Polymorphic inter-simple sequence repeat and sequence-related amplified polymorphism markers were used to analyze the genetic diversity of 78 P. cubensis isolates from Turkey, Czech Republic, and Israel (Polat et al. 2014). The data showed remarkable genetic diversity within and among the isolates. While isolates from Turkey and Czech Republic exhibited a rather uniform genetic background, isolates from Israel were clearly distinguished from the others. The results indicated possible recent migration and/or frequent sexual reproduction of the pathogen in Israel (Cohen and Rubin 2012).

Mating type and oospore formation. The occurrence of oospores in infected leaves was reported from several countries during the 20th century (Palti and Cohen 1980). Most reports were from Asia and one from Austria (Bedlan 1989). The mean diameter of oospores differs substantially in different host species and ranges from $22 \mu \mathrm{m}$ in Trichosanthes spp. (snake gourd) to $55 \mu \mathrm{m}$ in cucumber (Palti and Cohen 1980). Zhang et al. (2012) reported that oospores, normally occurring in cucumber leaves in China, could overwinter in soil in nature (at $-20^{\circ} \mathrm{C}$ ) and can cause infection in potted plants at spring time. Downy mildew pathogens may be homothallic (e.g., Plasmopara halstedii and Pseudoperonospora humuli) or heterothallic (Plasmopara viticola). No information was available on $P$. cubensis until 2010, when oospores were observed inside the mesophyll (Fig. 2B) after co-inoculation of sporangia from cucumber and butternut gourd onto detached cucumber or melon leaves (Cohen and Rubin 2012). Single sporangium isolates of A1 and A2 reference isolates were produced and used to analyze the $P$. cubensis population for mating type distribution in Israel. It became apparent that most isolates are heterothallic. Isolates collected from Cucumis spp. (cucumber and melon) during 2002 to 2014 belonged to the A1 mating type, whereas most isolates collected from Cucurbita spp. (squash, pumpkin, or butternut gourd) belonged to the A2 mating type. The A2 isolates are considered as newcomers (since 2010) in Israel and they all belong to pathotype 6. Rarely, the A1A2 mating type (Cohen and Rubin
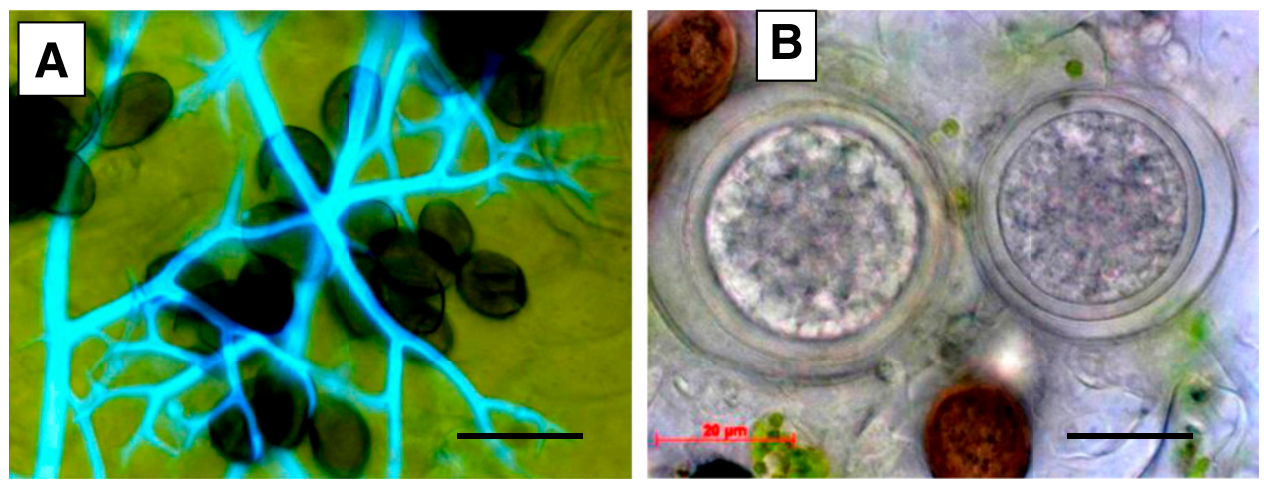

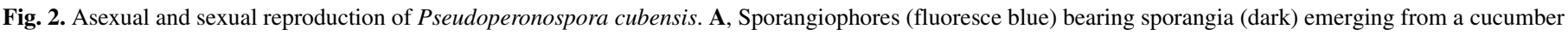

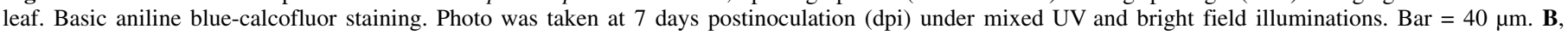

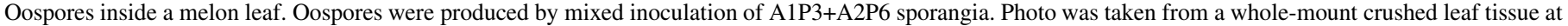
7 dpi. Bar $=20 \mu \mathrm{m}$. 
2012) was detected in the field and among F1 progeny isolates (A1A2 does not produce oospores when inoculated singly, but does when mixed inoculated with either A1 or A2). The A1 and A2 reference isolates were used to determine the mating type distribution in $P$. cubensis populations in other countries. The occurrence of A2 mating type isolates was confirmed in Ukraine in 2011, Russia in 2013, Kenya in 2012, and Angola in 2014 (Y. Cohen, A. E. Rubin, and N. Bibi, unpublished data), in China (Cohen et al. 2013b), Vietnam in 2013 (Y. Cohen, H. Nguyen, and A. Rubin, unpublished data), India in 2014 (Y. Cohen, A. E. Rubin and D. Chandramohan, unpublished data), France (Y. Cohen, M. Waldner-Zulauf, and A. E. Rubin, unpublished data), Germany (Y. Cohen, D. Hermann, and A. E. Rubin, unpublished data), and the United States (Thomas et al. 2013). In Vietnam, some isolates collected from bottle gourd were homothallic, producing oospores when inoculated singly onto melon leaves (Y. Cohen and A. E. Rubin, unpublished data).

No reports were available on oospore formation under laboratory conditions until the discovery of the A2 mating type in 2010 (Cohen and Rubin 2012). Co-inoculation with A1 and A2 sporangia produced abundant oospores in detached leaves of melon and cucumber (Fig. 2B). Oospores were produced within 5 to 7 days in melon and within 7 to 10 days in cucumber; optimal temperatures were at 15 to $20^{\circ} \mathrm{C}$. Only a few oospores were produced in other susceptible species of Cucurbitaceae. Oospores produced in the laboratory were infectious to detached leaves of cucumber, melon and butternut gourd (Cucurbita moschata) but not to pumpkin or squash. However, infectivity of oospores in the laboratory was quite erratic. No reports are available on oospore germination in vitro of $P$. cubensis (nor in P. humuli).

In several experiments, oospores were produced in melon leaves following co-inoculation with A1P3R and A2P6S isolates (A1 and A2 stands for mating type, P3 and P6 for pathotype and R and S for resistance and sensitivity to the fungicide mefenoxam). Single lesion sporangial isolates recovered from oospore-infected leaves segregated for resistance to mefenoxam as expected from $\mathrm{F} 1$ hybrids. Interestingly, all F1 progeny isolates recovered from cucumber were A1P3R while all recovered from butternut gourd were A2P6S. Some hybrids sporulated on bitter gourd and slightly so on watermelon (both parents did not), suggesting that sexual recombination may broaden the host range (Cohen et al. 2011; Falach 2014).

Races and pathotypes. Races may be distinguished by using a series of differentials (susceptible and resistant) of one host species. A new race of $P$. cubensis appeared in the United States in 2004 (Holmes et al. 2006). Pathotypes can be distinguished by using a set of different species of Cucurbitaceae. A simple differential set includes seven species (Thomas et al. 1987), while a more complicated set includes twelve species. Thomas et al. (1987) reported on pathotypes (P) 1 to 5 occurring in Japan, Israel, and the United States. The P1 pathotype attacks cucumber and netted melon; P2 attacks cucumber, netted melon and Cucumis melo var. conomon; $\mathrm{P} 3$ attacks cucumber, netted melon, C. melo var. conomon and $C$. melo var. acidulus; $\mathrm{P} 4$ attacks cucumber, netted melon, C. melo var. conomon, C. melo var. acidulus and watermelon; and P5 attacks cucumber, netted melon, C. melo var. conomon, C. melo var. acidulus, watermelon, squash, and pumpkin. The P1 and P2 pathotypes occurred in Japan, P3 in Israel, and P4 and P5 in the United States (Table 1). This distribution has since changed dramatically. For example, in Israel, P6 appeared in 2002 (Cohen et al. 2003) which does not attack watermelon. In Italy, P5 appeared in 2003 (Cappelli et al. 2003). In the Czech Republic, P. cubensis appeared for the first time on C. moschata in 2010 (Lebeda et al. 2011). Lebeda and Widrlechner (2003) reported on at least 15 different pathotypes. In recent surveys, we observed P7 in China, P8 in Vietnam (Y. Cohen and H. Nguyen, unpublished data), P9 in Russia (Y. Cohen and A. Artemyeva, unpublished data), and P10 in India (Bangalore area, Karnata Province) where heavy epidemics were observed on ridge gourd (Luffa acutangula) (Table 1). The disease also occurred on cucumber, snake gourd (Trichosanthes cucumerina), ash gourd (Benincasa hispida), and pumpkin (Y. Cohen and D. Chandramohan, unpublished data).

Host preference and incompatibility. Most isolates of the A2 mating type collected in Israel during 2002 to 2014 were from Cucurbita spp., while most A1 isolates were from Cucumis spp. (Cohen et al. 2013a). The isolates collected from Cucumis belonged to pathotype 3 and infect cucumber and melon only, whereas those collected form Cucurbita belonged to pathotype 6 and infect cucumber, melon, squash, pumpkin, and butternut gourd (but not watermelon or sponge gourd) (Fig. 3). Recent surveys in India (vicinity of Bangalore) showed that A2 isolates occur on cucumber, ridge gourd, pumpkin, snake gourd, and ash gourd, whereas A1 isolates were rarely retrieved (Y. Cohen and A. E. Rubin, unpublished data). To verify host preference, single-sporangium isolates of A1P3 and A2P6 were mixed at 1:1 ratio and inoculated onto nine cucurbit species in the field. Disease appeared earliest and progressed fastest in cucumber, moderately so in melon, and slowly in butternut gourd, squash, pumpkin, and bottle gourd. No symptoms developed in watermelon, sponge gourd, and bitter gourd. Infected leaves were periodically collected, and sporangia from each host were tested for mating type. Most leaves of

TABLE 1. Major pathotypes of Pseudoperonospora cubensis in seven countries around the globe

\begin{tabular}{|c|c|c|c|c|c|c|c|c|c|c|}
\hline \multirow[b]{4}{*}{ Host } & \multicolumn{10}{|c|}{ Pathotype, country, and year } \\
\hline & 1 & 2 & 3 & 4 & 5 & 6 & 7 & 8 & 9 & 10 \\
\hline & Japan & Japan & Israel & USA & USA & Israel & China & Vietnam & Russia & India \\
\hline & 1987 & 1987 & 1987 & 1987 & 1987 & 2002 & 2013 & 2013 & 2013 & 2014 \\
\hline Cucumis sativum (cucumber) & $\sqrt{ }$ & $\sqrt{ }$ & $\sqrt{ }$ & $\sqrt{ }$ & $\sqrt{ }$ & $\sqrt{ }$ & $\sqrt{ }$ & $\sqrt{ }$ & $\sqrt{ }$ & $\sqrt{ }$ \\
\hline Cucumis melo reticulatus (netted melon) & $\sqrt{ }$ & $\sqrt{ }$ & $\sqrt{ }$ & $\sqrt{ }$ & $\sqrt{ }$ & $\sqrt{ }$ & $\sqrt{ }$ & $\sqrt{ }$ & $\sqrt{ }$ & $\sqrt{ }$ \\
\hline Cucumis melo conomon (pickling melon) & & $\sqrt{ }$ & $\sqrt{ }$ & $\sqrt{ }$ & $\sqrt{ }$ & $\sqrt{ }$ & $\sqrt{ }$ & $\sqrt{ }$ & $\sqrt{ }$ & $\sqrt{ }$ \\
\hline Cucumis melo acidulus (oriental melon) & & & $\sqrt{ }$ & $\sqrt{ }$ & $\sqrt{ }$ & $\sqrt{ }$ & $\sqrt{ }$ & $\sqrt{ }$ & $\sqrt{ }$ & $\sqrt{ }$ \\
\hline Citrullus lanatus (watermelon) & & & & $\sqrt{ }$ & $\sqrt{ }$ & & & $\sqrt{ }$ & $\sqrt{ }$ & $\sqrt{ }$ \\
\hline Cucurbita pepo (squash) & & & & & $\sqrt{ }$ & $\sqrt{ }$ & $\sqrt{ }$ & & $\sqrt{ }$ & \\
\hline Cucurbita maxima (pumpkin) & & & & & $\sqrt{ }$ & $\sqrt{ }$ & $\sqrt{ }$ & & $\sqrt{ }$ & $\sqrt{ }$ \\
\hline Cucurbita moschata (butternut gourd) & & & & & & $\sqrt{ }$ & $\sqrt{ }$ & & $\sqrt{ }$ & $\sqrt{ }$ \\
\hline Lagenaria vulgaris (bottle gourd) & & & & & & $\sqrt{ }$ & $\sqrt{ }$ & $\sqrt{ }$ & $\sqrt{ }$ & $\sqrt{ }$ \\
\hline Luffa cylindrica (sponge gourd) & & & & & & & $\sqrt{ }$ & $\sqrt{ }$ & & $\sqrt{ }$ \\
\hline Luffa acutangula (ridge gourd) & & & & & & & $\sqrt{ }$ & $\sqrt{ }$ & & $\sqrt{ }$ \\
\hline Luffa aegyptica (spot gourd) & & & & & & & & & & $\sqrt{ }$ \\
\hline Momordica balsamina (bitter gourd) & & & & & & & & $\sqrt{ }$ & & $\sqrt{ }$ \\
\hline Benincasa hispida (ash gourd) & & & & & & & & $\sqrt{ }$ & & $\sqrt{ }$ \\
\hline Trichosanthes cucumerina (snake gourd) & & & & & & & & & & $\sqrt{ }$ \\
\hline Humulus lupulus (hop) & & & & & & & & & $\sqrt{ }$ & \\
\hline
\end{tabular}


cucumber carried A1, whereas all leaves of squash, pumpkin, and butternut gourd carried A2 isolates; melon and bottle gourd carried both mating types (Falach 2014). It is assumed that mating type and virulence are genetically unlinked but experimental evidence is lacking.

Laboratory studies have shown profuse sporulation of A1P3 isolates on cucumber, moderate on melon and slight sporulation on bottle gourd. A1P3 isolates produced HR-like symptoms with no sporulation when inoculated onto detached leaves of butternut gourd, squash or pumpkin. In contrast, A2P6 isolates were compatible with all six plant species (Fig. 3). A2P6 isolates were reported to have a broader host range but lower rate of multiplication as compared with A1P3 isolates (Falach 2014). The differential compatibility of A1P3 versus A2P6 isolates with various hosts fits nicely with their differential ability to produce oospores in various hosts. P. cubensis is heterothallic and both mating types have to infect the host in order to reproduce sexually. Cucumber and melon enabled oospore production because they are compatible with both A1P3 and A2P6 isolates. However, squash, pumpkin and butternut gourd are incompatible with A1P3 isolates, and therefore produce no oospores upon co-inoculation with A2P6 isolates (Cohen and Rubin 2012). A1P3 isolates normally produce HR-like symptoms on bottle gourd and only rarely shows sporulation (Fig. 3); also oospores formation in this species is very rare (Y. Cohen and A. E. Rubin, unpublished data). Infection capacity is an important fitness parameter. Laboratory studies showed that one sporangium of A1P3 isolates is sufficient to produce a lesion in cucumber, while 10 sporangia are required for A2P6 isolates (Falach 2014).

Seed transmission. Cohen et al. (2014) have recently reported, for the first time, that $P$. cubensis occurs in the seed-cavity of fruits and seeds of infected cucurbit plants but not in healthy plants. Using polymerase chain reaction (PCR), artificial inoculation, and microscopy, they showed that the pathogen can occur in ovaries, fruits, and embryos of various cucurbit species. About $0.9 \%$ of the seeds tested produced infected plants, and although this is very low, it suggests the potential of seed transmission of P. cubensis. Recent data (Y. Cohen and M. Galperin, unpublished data) showed that some commercial F1 squash seeds grown aseptically have produced infected plants within 3 weeks. It seems that this air- and leafborne pathogen has become fruit- and seedborne, and therefore, may have the potential to be transported via seed in commercial trade to new habitats.

Isolate-specific host resistance. The wild cucumbers PI330628 (Afghanistan) and PI-197088 (India) were found to be highly resistant against multiple isolates of $P$. cubensis under laboratory, greenhouse and field conditions in Israel (Fig. 4). Plants of the F2 progeny from a cross between each PI and the susceptible cucumber SMR-18 showed different segregation ratios, depending on the isolate used for inoculation (Chen and Cohen 2013). While the parents PI 330628 and PI 197088 were resistant to isolates A, B, and $\mathrm{C}$ and the parent SMR-18 was susceptible, the F1 plants were resistant to isolates $\mathrm{A}$ and $\mathrm{B}$ but susceptible to isolate $\mathrm{C}$. The F2 population segregated at a ratio of $3: 1$ (resistant: susceptible) to isolate A, 9:7 to isolate $B$ and 1:3 to isolate $C$. The data suggest that each $P$. cubensis isolate recognized a specific subset of the many resistance loci carried by wild type cucumbers. Under field epiphytotic conditions, both F2 populations segregated at 1:14:1 (resistant: moderately susceptible: susceptible), suggesting that resistance against field isolates is controlled by two incompletely dominant complimentary genes.

\section{GENETIC HOST RESISTANCE}

The downy mildew problem. In the eastern United States, downy mildew represents a major problem for cucurbit growers. Highly resistant cultivars were available to growers for much of the second half of the 20th century (Sitterly 1973; Wehner and Shetty
1997). Cultivars now used by growers have at least a moderate level of resistance tracing back to Plant Introduction (PI) accession 197087 (Barnes and Epps 1954). In the 1950s, while working at Clemson University, Carroll Barnes developed a series of resistant cultivars, including the following: 'Polaris', 'Poinsett', 'Pixie', and 'Chipper' using the resistance source PI 197087. With the release of 'Polaris' in 1961, resistant cultivars were available through 2003, since $d m-1$ resistance gene from PI 197087 provided growers with genetic control of downy mildew. During this period, downy mildew was only a moderate problem in North America and was easily controlled with fungicides. A flare-up of the disease between 1982 and 1988 resulted in incidence levels as high as 30\% in North Carolina (St. Amand and Wehner, 1991). Since the emergence of a 'new' population of $P$. cubensis in 2004, the disease severity and yield losses have been significantly higher than in the previous years. In 2004 alone, the presence of a more virulent race of P. cubensis caused yield losses of $40 \%$ for cucumber growers in the United States (Colucci et al. 2006). Ten years later, the new race continues to infect cucumber in most production areas in the United States. Most cultivars grown have some resistance. However, the observed level of resistance is significantly lower than that observed before 2004. This has resulted in increased costs to growers, as fungicides are now required to produce cucumbers with acceptable yields and quality. P. cubensis has a history of evolving resistance to fungicides (Pappas 1982; Bains and Sharma 1986; Cohen and Samoucha 1984) and recent reports indicate that the new races are likely to follow this development (Adams and Quesada-Ocampo, 2014; Zhu et al. 2007). Development of new cultivars with high resistance is required for improving the stability of cucumber production.

History of host resistance. In 1933, a long-fruited Chinese cultivar was used at the Puerto Rico Agricultural Experiment Station as a source of resistance to downy mildew. The Chinese cultivar was commercially unviable except as a trellis type. Researchers combined that resistance with good horticultural traits and released seven lines (the top three were P.R. 37, P.R. 39, and P.R. 40) with fruit quality and yield at least as good as the checks. These lines were used by the Clemson University program for the development of resistant cultivars (Barnes et al. 1946; Barnes 1955; Barnes and Epps 1955). Fifteen years after the resistant Chinese cultivar was used, Barnes (1948) released the downy mildew resistant cultivar Palmetto using the resistance of P.R. 40 and the quality of 'Cubit'. A limited area was planted to 'Palmetto' in 1948 and 1949. Symptoms during those years were classified as small lesions with little sporulation (Epps and Barnes 1952). By 1950 and 1951, all fields planted with 'Palmetto' showed significant infections with large lesions and heavy sporulation as in susceptible cultivars. This shift was caused by a mutation, selection in a mixed population, and/or migration of new races from different regions.

Following the failed resistance of 'Palmetto' and P.R. 40, Barnes and Epps (1954) identified a new source of resistance, PI 197087. Since its identification, resistance in PI 197087 has been introgressed into many cultivars that has conferred resistance to the pre-2004 downy mildew pathogen population in the United States. This resistance was effective in controlling downy mildew for nearly 50 years. Since the emergence of new downy mildew races in 2004, sources of high resistance (reduced leaf damage) and tolerance (good yield under disease presence) have been identified. Criswell (2008) and Call et al. (2012b) identified several sources of resistance to the new downy mildew races in a cucumber germplasm screening and a multiyear evaluation of the most resistant genotypes. The most resistant genotypes were PI 197088, Ames 2354, PI 267942, Ames 2353, PI 197085, PI 330628, PI 432878, and PI 618931 (Criswell 2008). A larger study is in Call et al. (2012b). Innark et al. (2014) evaluated, in Thailand during 2006 to 2009, the resistance of 40 cucumber accessions from Asia. They found PI 489752 from China highly resistant. The identification of resistant sources to the new populations will allow researchers to develop new cultivars with high levels of resistance. 
Inheritance of resistance genes. Angelov (1994) reported that resistance of PI 197088 to the European P. cubensis races was due to two recessive genes (no names assigned), while resistance in 'Poinsett' was from one recessive gene $(d m-1)$. Resistance in 'Poinsett', 'Taipei', 'Natsufushinari', PI 179676, and PI 234517, which traces to PI 197087, was reported by Van Vliet and Meysing $(1974 ; 1977)$ to be from at least one single recessive gene, $d m(d m-1)$. Fanourakis and Simon (1987) agreed with Van Vliet and Meysing, confirming that a single recessive gene controls downy mildew resistance. In contrast to the single-gene models, Shimizu et al. (1963) reported that three recessive genes $\left(s_{1}, s_{2}\right.$, and $\left.s_{3}\right)$ control resistance in 'Aojihai'. McFerson (1978) also reported that resistance was due to three recessive genes. Doruchowski and Łazokowska-Ryk (1992) reached the same conclusion using 'Wisconsin 2843' (resistance from PI 197087) and indicated that resistance to downy mildew is under the control of three recessive genes $(d m-1, d m-2$, and $d m-3)$. Interestingly, they reported that $d m-3$ and either $d m-1$ or $d m-2$ had to be homozygous recessive for maximum resistance expression. In contrast to Doruchowski and Łazokowska-Ryk (1992), Petrov et al. (2000) suggested that inheritance in J-13, a derivative of Wisconsin 2843, may be due to one or two incompletely dominant genes. Pershin et al. (1988) determined that resistance was controlled by at least three major genes, all with partial dominance using cultivar Sadao Rischu. Recently, Kozik et al. (2013) reported that one to three genes may control resistance in Ames 2354, a downy mildew tolerant selection from PI 234517 (Carroll Barnes breeding line SC50). Similarly, Call (2012) reported that resistance in PI 197088 is likely due to at least three genes. Resistance in cultivars Palmetto and Yomaki, with resistance tracing back to P.R. 40 (Barnes 1948), was reported to be the result of an epistatic interaction between a dominant susceptible allele and a recessive resistance allele (El-Hafaz et al. 1990). Similarly, Badr and Mohamed (1998) reported that a pair of dominant and recessive interacting genes controls resistance.

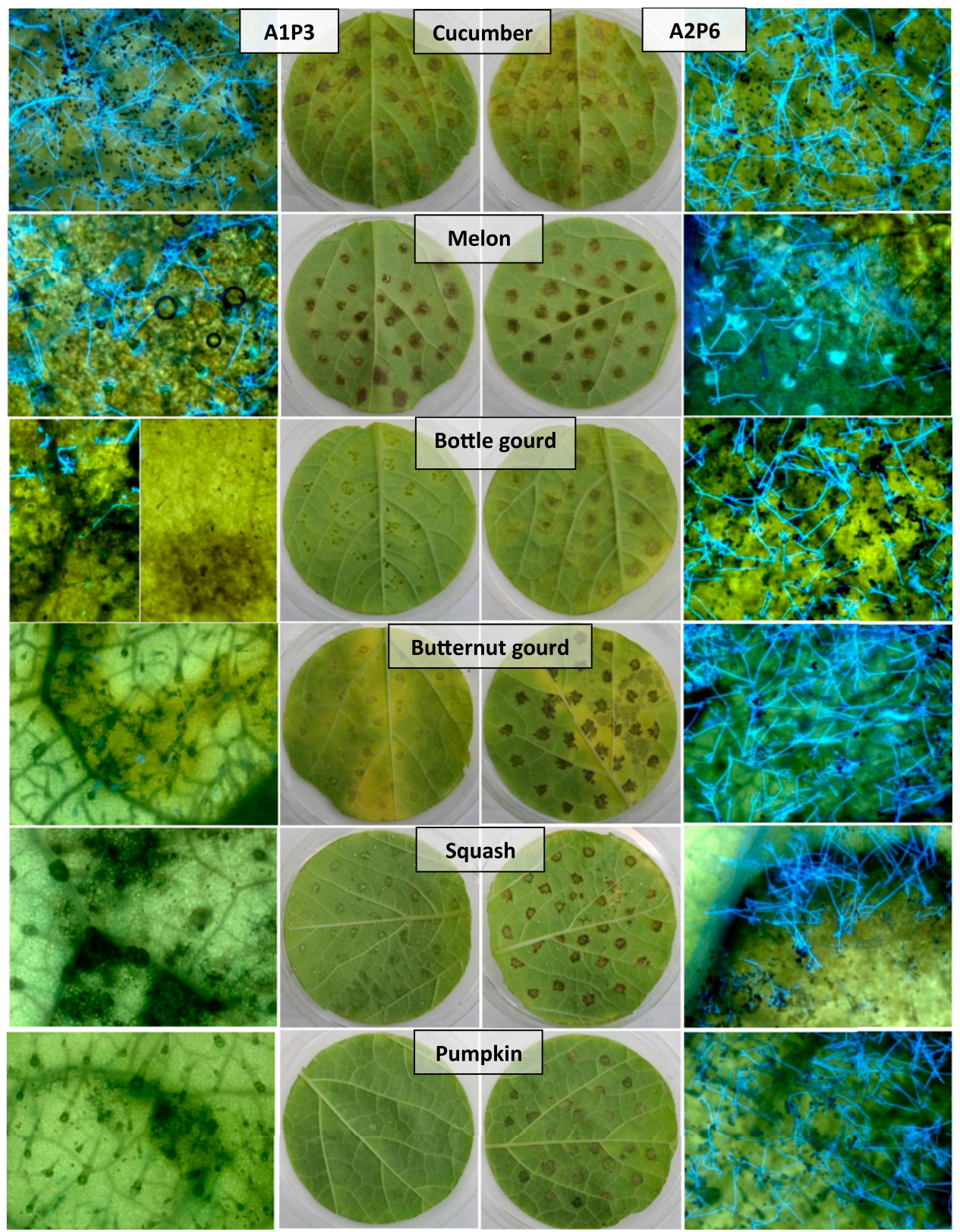

Fig. 3. Pathogenicity of Pseudoperonospora cubensis A1P3 (mating type A1 pathotype 3) and A2P6 (mating type A2 pathotype 6) on 8-cm-diameter leaf discs of six species of Cucurbitaceae. At 7 days postinoculation (dpi), $10 \mathrm{~mm}$ leaf discs were removed and boiled in ethanol for 5 min. The discs were placed in basic aniline blue for $24 \mathrm{~h}$, and then stained with calcofluor and examined under mixed UV and bright field illuminations. Sporangiophores of the pathogen fluoresce blue. Note that A1P3 induces hypersensitive-like response in butternut gourd, squash, and pumpkin. 
Conflicting inheritance reports. There appears to be no general consensus in the literature about the inheritance pattern of resistance. This may be due to several factors that include differences in measuring techniques, pathogen and environmental variability, and resistance sources. For instance, the aforementioned studies were not all measuring the same disease symptoms. Further, Doruchowski and Łazokowska-Ryk (1992) measured percentage of necrotic lesions, while Van Vliet and Meysing $(1974 ; 1977)$ and El-Hafaz et al. (1990) measured sporulation intensity. Other studies used different measures of disease, including percentage of chlorotic lesions (Fanourakis and Simon 1987; Petrov et al. 2000). Criswell (2008) and Call et al. (2012a; 2012b) reported that necrosis and chlorosis were highly correlated. However, sporulation and stunting were only mildly correlated with chlorosis and necrosis.

By using different measures to quantify disease, it is possible that different researchers could have estimated inheritance for different traits. In addition, the above inheritance studies were conducted in different environments. Weather factors such as temperature, humidity, and rainfall influence inoculum dispersal and availability and in turn influence the degree and extent disease severity (Cohen 1977). It is reasonable to assume that the environment was different in the studies since they were conducted over a 50 year period, and in different countries. Furthermore, $P$. cubensis exhibits a high degree of variation on a temporal and spatial scale (Lebeda and Urban 2004). Multiple pathotypes and races have been identified in different areas (Angelov et al. 2000; Epps and Barnes 1952; Hughes and Van Haltern 1952; Lebeda and Widrlechner 2003; Shetty and Wehner 2002). Finally, the source of resistance varies over the downy mildew studies. Historically, two primary sources of resistance have been used for cultivar development and inheritance studies. Some studies evaluated resistance sources from PI 197087 or PI 197088 (India), while others evaluated resistance from P.R. 40 (China). Recent inheritance studies include the new source of resistance, PI 197088, adding new information and complexity to this area of study (Van den Langenberg, 2014).

Several inheritance patterns have been proposed for resistance to downy mildew. These range from single-gene inheritance to at least three genes with varying degrees of dominance or epistasis (summarized in Wang et. al 2014). Resistance of PI 197088 or PI 330628 was inherited in an isolate-dependent manner (Chen and Cohen 2013). Despite this incongruence, there are at least four known resistance sources to the different downy mildew populations: P.R. 40, PI 197087, PI 330628, and PI 197088. Presently, resistance tracing to P.R. 40 now provides only a slight advantage over lines that lack a resistant parent in their pedigree. Cultivars with resistance tracing to PI 197087 are moderately resistant to the current downy mildew populations in the United States comprising a majority of the cultivars in use, and require frequent fungicide applications. Finally, the newly identified sources, PI 330628 and PI 197088, are highly resistant (Fig. 4) and are being used to develop new cultivars. A robust, reliable and consistent way for measuring resistance is currently used to achieve this goal. However, poor horticultural traits (e.g., fruit shape and rind structure, mode of flowering) make it more difficult to introgress resistance into adapted cultivars.

Current research on cucumber resistance. Currently, none of the commercial cultivars offer a high level of resistance to downy mildew (Call et al. 2012a). In general, commercial cultivars range from moderately resistant to highly susceptible cultivars and require fungicide applications to protect yield and quality. Since the emergence of new downy mildew races, research has focused on the identification of new sources of high resistance and the incorporation of those traits into elite backgrounds (Call et al. 2012b). In 2014, Holdsworth et al. (2014) released a breeding line, DMR-NY264, with high resistance and high yield under disease pressure. While DMRNY264 appears to have high resistance and fruit quality compared with resistant PI accessions and commercial checks under disease pressure, fruit set is late in the season. In their study, the authors partition the yield measurements into two groups, harvests 1 to 6 (early) and 7 to 12 (late) and commercial checks outperformed DMRNY264 during the early period when disease incidence is low, and then had lower yields in late harvests when disease incidence is high. However, the public release of a breeding line with high resistance and good quality provides private and public breeders with new germplasm for commercial cultivar development.

Evolutionary potential. Cohen and Rubin (2012) reported that $P$. cubensis reproduces both sexually and asexually. Additionally, sporangia of $P$. cubensis may travel long distances rapidly (Lange et al. 1989; Thomas 1996, Ojiambo and Holmes 2011). According to McDonald and Linde (2002), a mixed mating system along with airborne dispersal of inoculum represents the highest possible evolutionary potential. Mating may result in the evolution of recombinant isolates with enhanced aggressiveness and expanded host range (Cohen and Rubin 2012). Based on this rating, P. cubensis has the potential to rapidly overcome genetic host resistance and evolve resistance to fungicides. Despite the high evolutionary potentially, the single gene resistance deployed in 1961 was an effective control measure against infections through 2003. As fungicide resistance continues to develop (against phenylamides, carboxylic acid amides, and strobilurins, described below) the importance of new cultivars with genetic resistance will continue to increase.

Molecular markers for resistance to $\boldsymbol{P}$. cubensis. Several studies have been conducted to identify QTL associated with resistance to downy mildew (Innark et al. 2014; Wang et al. 2014). Zhang et al. (2013) mapped five putative QTL (dm1.1, dm5.1, $d m 5.2, d m 5.3$, and $d m 6.1)$ on chromosomes 1,5 , and 6 in an $\mathrm{F}_{2}$ cucumber population using a cross between $\mathrm{K} 8$ and $\mathrm{K} 18$. Inbred line $\mathrm{K} 8$ is a northern Chinese type cucumber inbred with resistance to downy mildew derived from a Chinese long cucumber hybrid, 'Yuanfeng', K18 is highly susceptible to downy mildew (Zhang et al. 2007). Similarly, Bai et al. (2008) mapped four QTL (dm1.1, $d m 1.2, d m$ 6.1, and $d m 6.2$ ) to linkage groups 1 and 6 in a recombinant inbred line (RIL) population with resistant parent S94 (northern Chinese type cucumber). However, they were unable to assign the linkage groups to corresponding chromosomes. Pang et al. (2013) identified three putative QTL controlling aspects of resistance to downy mildew by screening 10 introgression lines derived from an interspecific hybridization between cucumber cultivar Beijingjietou and wild Cucumis hystrix. Ding et al. (2007) reported that the randomly amplified polymorphic DNA (RAPD) marker, SPS18-561, was linked to a downy mildew resistance gene. Horejsi et al. (2000) identified five RAPD markers linked to downy mildew resistance in 'WI 1983G', a resistant inbred derived from 'Gy 14', tracing its resistance back to PI 197087. Additional

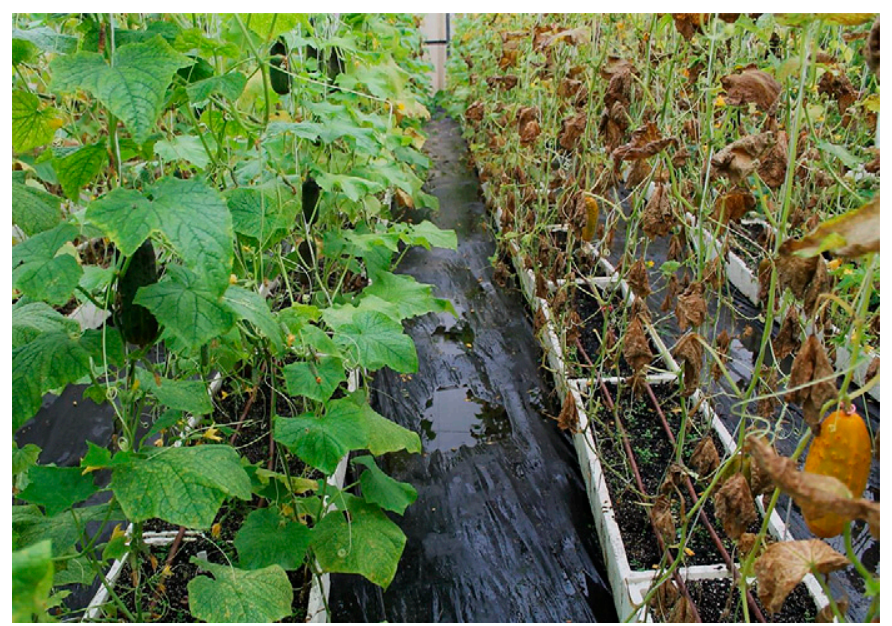

Fig. 4. Downy mildew resistant inbred line (F3OC1) of cucumber (left) derived from PI 330628 and its susceptible parental line SMR-18 (right). Natural epidemic in a net-house, Bar-Ilan University Farm, Israel, November 2014. 
non-PCR markers linked to downy mildew resistance have also been reported. However, due to the high inefficiency and cost of non-PCR markers they provide little value to molecular assisted breeding programs (Bai et al. 2008; Ding et al. 2007; Horejsi et al. 2000; Kennard et al. 1994; Meglic and Staub 1996). While the information regarding the location and effect of the various QTL and molecular markers is useful for breeders and researchers, none of these studies trace resistance back to PI 197088 or other newly identified sources of resistance. This suggests that many of the identified QTL in the aforementioned studies are likely the $d m-1$ gene from PI 197087.

Recently, Yoshioka et al. (2014) reported 11 QTL with relatively small effects associated with downy mildew resistance in the cucumber line CS-PMR1, a selection derived by self-pollination of PI 197088. A population consisting of 111 RILs derived from a cross between CS-PMR1 and moderately resistant 'Santou', an old Japanese cultivar, was used for QTL analysis. A single isolate of $P$. cubensis from cucumber was used as the source of all inoculum. All phenotype data were collected in a greenhouse. This study represents the only known example of QTL discovery using the new source of resistance found in PI 197088 and is an important step in allowing breeders to integrate molecular data into their programs. However, greenhouse and single-isolate assays of resistance are not representative of field populations and results should be confirmed using field test in multiple locations.

\section{EPIDEMIOLOGY}

Pathogen dispersal in U.S. populations. $P$. cubensis can only survive and reproduce on living host tissue (Savory et al. 2011) and overwinters only in geographical areas that experience no killing frost (in areas such as Gulf of Mexico, Southern Florida, and Southern Texas). In early spring, asexual sporangia are produced on infected cucurbit leaves and released into the air traveling long distance through wind dispersion (Lange et al. 1989; Thomas 1996; Ojiambo and Holmes 2011). It is believed that downy mildew infection patterns follow spring wind currents flowing northward from these overwintering areas (Doran 1932; Holmes et al. 2004; Van Haltern 1933). Once the pathogen establishes disease in any particular geographic region, local secondary infections occur primarily via wind, splash dispersal, and physical transfer on equipment (Thomas 1996). Oospores of P. cubensis have been observed in both temperate and tropical regions (Bains et al. 1977; Bedlan 1989; Cohen et al. 2003; D'Ercole 1975; Hiura and Kawada 1933; Palti and Cohen 1980). The potential exists that oospores could act as additional overwintering structures; however, their importance in the disease cycle remains to be studied.

The overwintering nature of $P$. cubensis plays a fundamental role in the temporal and spatial spread wherever the disease occurs. Given that cucurbits are sensitive to frost, disease occurrence in locations in northern states of the United States depends on the annual introduction of inoculum from the south (Ojiambo et al. 2011). This yearly introduction of $P$. cubensis sporangia from overwintering sources has provided a frame to study the temporal and spatial spread of the disease and establish the effective longdistance spread (Granke and Hausbeck 2011; Ojiambo and Holmes 2011). This information has also been essential to forecast (Ojiambo et al. 2011) and establish the risk of disease occurrence in cucurbit fields (Ojiambo and Kang 2013). On a temporal scale, records of disease observations collected in the United States indicate very sporadic disease early in the season, with an exponential increase in June after which the epidemic enters in a stationary phase around October. The duration of the epidemic, i.e., the time from the first to the last outbreak, is much longer in the southern than in northern states suggesting more opportunities for pathogen reproduction and transmission in the south compared with northern states. The season-long rate of temporal spread has been estimated at approximately two new outbreaks per day (Ojiambo and Holmes 2011). The disease surveillance system (Ojiambo et al. 2011) used as the basis of forecasting the first disease outbreaks provides enhanced monitoring data that sufficiently serves as an early warning system for commercial cucurbit production.

Disease outbreak and risk of spread. In the eastern United States, the disease wave front has been determined to advance northward at a rate of $\sim 11 \mathrm{~km} /$ day (Ojiambo and Holmes 2011). Using calculations on the nearest neighbor distances of spread, disease outbreaks have been found to be spatially aggregated and disease spread was more likely at distances of 90 to $120 \mathrm{~km}$ or less (Ojiambo and Holmes 2011). Analysis of outbreaks across the eastern United States has shown that the extent of spatial aggregation, which is equivalent to the mean distance of dispersal, is $\sim 1,000 \mathrm{~km}$ (Ojiambo and Holmes 2011). The latter suggests that in the United States overwintering sources in the south can provide initial inoculum directly to states in the lower mid-Atlantic region. In addition, disease outbreaks in upper Mid-Atlantic and Great Lakes Region could be also from other sources such as local greenhouses. The risk of disease outbreak in space and time is very large indicating that factors such as availability of host and weather variables that prevail on a regional scale influence disease outbreak. Clustering of outbreaks in space and time is considered to be an indicator of the infectious nature of a disease (Picado et al. 2007). For cucurbit downy mildew, both temporal and spatial components of the space-time continuum increase during the epidemic suggesting that there is an increase in local-spread distances, and fields remain infectious for a long period. This implies that enhanced monitoring of new outbreaks and immediate applications of disease control measures are the main options to slow the spread of the epidemic wave front. In general, the risk of disease outbreak is high in the midAtlantic region showing clustering of outbreaks at the state level and indicating that states in the mid-Atlantic region and host-factors play a significant role in the risk of disease outbreak (Ojiambo and Kang 2013). The high risk of disease outbreaks in states in the mid-Atlantic region indicates that disease monitoring will need to be intensified in these states and in fields with fungicide treatments once an infection is observed in the region.

Initial inoculum. The annual introduction of initial inoculum from overwintering sources is based on the assumption that no oospores are present in cucurbit fields. Analysis of disease outbreaks showed that in up to $5 \%$ of cases outbreaks were inconsistent with the annual northward advance of the epidemic in the eastern United States (Ojiambo et al. 2011). This suggests that other sources of initial inoculum besides the overwintering sources in the south may exist. One possibility is overwintering inoculum in local greenhouses. Production of cucumber in year-round greenhouses in Michigan and Canada could be potential sources of inoculum during the season, particularly when disease control measures are inadequate. The other possibility is the presence of oospores in cucurbit fields that have yet to be detected in nature. Past efforts to find oospores in nature or under laboratory controlled conditions in the United States were not successful (G. J. Holmes and P.S. Ojiambo, unpublished data). This is not surprising since sexual reproduction in P. cubensis seems to be rare and oospores have been observed on a limited scale (Lebeda and Cohen 2011). Recently, the presence of both A1 and A2 mating type isolates was demonstrated in the United States (Thomas et al. 2013). Oospores were produced in leaf tissue when isolates originating from different fields in eastern United States were crossed with either A 1 or A2 reference isolates. The A1 mating type was primarily associated with cucumber, while the A2 mating type was associated with cucurbits other than cucumber (Thomas et al. 2014). This suggests that $P$. cubensis may overwinter as oospores in the United States also in the absence of living host tissue serving as a local source of initial inoculum. It is not clear whether both A1 and A2 strains were present in the United States before the resurgence of the disease in 2004. However, it is reasonable to assume that only one of the two mating types was present in the United States prior to 2004, and that the other mating type was an introduction that could possibly coincide with the 
appearance of more aggressive isolates in 2004. As was observed in Israel (Cohen et al. 2003), pathotype 6 was recently also detected in the United States being associated with A1 and A2 mating type (Thomas et al. 2014).

Weather conditions. Temperature, moisture and the interaction of these two weather variables play a key role in the infection, sporulation and spread of $P$. cubensis. When disease epidemics occur, deviations from established thresholds of weather variables necessary for infection and sporulation can indicate a possible change in the composition of the pathogen population. Earlier studies on $P$. cubensis reported temperatures between 15 to $20^{\circ} \mathrm{C}$ (Cohen and Rotem 1969) and $2 \mathrm{~h}$ as the minimum duration of leaf wetness required for infections to occur on cucurbits (Cohen 1977). In the absence of enough leaf wetness, the effect of all other weather variables on disease development is very small (Palti and Cohen 1980). Optimal temperatures are important in determining the level of disease severity (Arauz et al. 2010). In a recent study (Arauz et al. 2010; Neufeld and Ojiambo 2012), sporangial germination and infection were reported to occur at up to 30 to $35^{\circ} \mathrm{C}$, which is much higher than reported in previous studies (Cohen 1977). This broadening in the range of maximum temperatures for infection suggests a possible change in the population structure of $P$. cubensis. The emergence of new, highly aggressive populations has been reported in the United States in 2004 (Colucci 2008). Isolates adapted to higher temperatures are expected to cause disease longer in the growing season and thereby result in higher yield losses. The impact of elevated temperatures on germination, infection, latent period, sporulation, reproduction and survival of $P$. cubensis is yet to be determined. It has been observed that increased aggressiveness of a pathogen is a result of high pathogenic fitness and high potential to survive (Van der Plank 1968). Therefore, new, more aggressive $P$. cubensis isolates (races, pathotypes, mating types) can be expected to eventually replace the pre-existing isolates. Generally, when more aggressive isolates have replaced existing populations, they have been attributed to introduction of new individuals rather than evolution of old ones (Milus et al. 2009; Wellings 2007). Thus, it is highly possible that the resurgence (re-emergence) of cucurbit downy mildew epidemics observed in 2002 in Israel (Cohen et al. 2003), in 2004 in the United States (Holmes et al. 2006) and in 2009 in Europe (Pavelková et al. 2011, Lebeda et al. 2011, 2012, 2013a), is likely due to introduction of strains from East Asia, probably by seeds (Cohen et al. 2014), first to Europe and then to the United States, as suggested by Runge et al. (2011).

\section{POPULATION GENETICS}

Survival and migration. In the United States, the pathogen is believed to survive the winter in regions below the 30th latitude (such as southern Florida) and disperse yearly toward northern states (Ojiambo et al. 2011). In addition, wild and weedy hosts have been identified in the United States (Wallace et al. 2014) and Europe (Runge and Thines 2009), which could provide a natural reservoir for $P$. cubensis in addition to the "green bridge" provided by yearround production of cucumbers in greenhouses (Savory et al. 2011). In northern U.S. regions, where the pathogen cannot overwinter, greenhouses may serve as an early inoculum source. Ontario is the number one producer of greenhouse-grown cucumbers in Canada, while in Michigan many greenhouse growers have transitioned from floriculture to vegetables. This shift has been spurred by consumer preference for locally grown produce during the winter/spring months when field-grown crops are not available. Seasonal cucumber greenhouse production in the United States begins in early fall and can continue through early summer, when field-grown cucumbers dominate the markets. These prolonged growing periods provide opportunities for the pathogen to overwinter; in fact, cucurbit downy mildew has been found in many such greenhouses (M. Hausbeck, personal communication). According to the cucurbit downy mildew (CDM) IPM-PIPE reports for 2009, the first reported occurrence of cucurbit downy mildew in North Carolina was 5 June, 4 days after sporangia were detected in Michigan (http://cdm.ipmpipe.org) (Granke and Hausbeck 2011). Understanding the role that natural or man-made reservoirs (greenhouses) could be playing in yearly epidemics would facilitate improvement of forecasting systems since what appears to be a sporadic outbreak could be linked to occurrence of susceptible wild hosts or other reservoirs in a region. Availability of reservoirs for the pathogen in combination with airborne dispersal can be problematic for disease control, as virulent or fungicide-resistant isolates can survive the winter and quickly spread throughout the country in spring. For example, data from Georgia efficacy trials during 2012 on cucumber showed reduced disease control with fluopicolide (Langston and Sanders 2013), a relatively new fungicide providing excellent disease control in previous years. The following year, data from North Carolina (Adams and Quesada-Ocampo 2014) and Michigan (Hausbeck and Linderman 2014) showed that fluopicolide was no longer effective enough for consistent downy mildew control in cucumber.

Molecular genotyping of U.S. populations. Current pathogen populations infecting cucurbit crops in the United States and other countries have been characterized with molecular markers (Quesada-Ocampo et al. 2012) revealing the importance of host and geography in shaping pathogen population structure. Over 400 $P$. cubensis isolates from 13 states were characterized using single nucleotide polymorphisms (SNPs) identified in five nuclear and two mitochondrial genes selected based on phylogenetic studies in other oomycetes. Data revealed high genetic diversity within $P$. cubensis isolates affecting cucurbit crops in the United States, and isolates frequently infecting cucumbers were genetically different from those infecting other cucurbits (Quesada-Ocampo et al. 2012). Recent findings of two lineages have been corroborated using comparative genomic analyses of nine $P$. cubensis individuals (Thomas et al. 2014). Population analyses also indicated that in some states such as North Carolina and Florida populations are highly diverse compared with other regions (Quesada-Ocampo et al. 2012). This high population diversity could be, in part, due to regional host availability. A recent study evaluated the susceptibility of melon cultivars to cucurbit downy mildew in South Carolina and Michigan (Cespedes-Sanchez et al. 2015). South Carolina has a highly diverse set of cultivated and wild cucurbit hosts, while in Michigan, predominantly cucumbers are grown. Disease severity was frequently higher in South Carolina. The unexpected genetic diversity of $P$. cubensis populations has important implications for development of diagnostics and disease management strategies since detection assays and control methods would need to be robust enough to take into account the diversity among all isolates.

The genome of an isolate of $P$. cubensis collected from cucumber in Ohio has been sequenced since the initial worldwide population study (Savory et al. 2012a) providing a wealth of information to develop markers for additional population analyses. Microsatellite (simple sequence repeat, SSR) markers have recently been generated from the $P$. cubensis genome (Wallace and QuesadaOcampo 2014). The MIcroSAtellite (MISA) identification tool was used to extract locations and frequencies of 2 to $6 \mathrm{bp}$ repeats from the $P$. cubensis transcriptome. Approximately $12 \%$ of the 23,522 transcripts examined contained an SSR. Most identified SSRs were trimers, making up to $61 \%$ of total SSRs, the most common repeat motif being AGC/CTG. A recent study using a subset of these SSRs revealed a rather diverse population structure within and among fields in Michigan and Canada. In Michigan, three of the five counties did not experience a shift in population structure from August to September. In Michigan and Canada, changes in population structure were detected between August and September. New genotypes became prominent as the season progressed, while some genotypes were no longer detected. These temporal shifts in population structure could be the result of new isolates moving into 
the region from southern states. Studies to evaluate the temporal population structure could add insight into the migration of $P$. cubensis isolates and direct regional management strategies.

Gene expression. The $P$. cubensis genome has also prompted gene expression analyses to characterize host-pathogen interactions (Adhikari et al. 2012; Burkhardt and Day 2014; Savory et al. 2012b). An initial pyrosequencing effort identified 61 of 454 sequences in the P. cubensis genome to contain an RXLR or a QXLR motif, which are also found in known oomycete effectors (Tian et al. 2011). A subsequent study that generated the current $P$. cubensis genome using Illumina sequencing identified 271 effectors containing the RXLR or QXLR motif (Savory et al. 2012a). High throughput whole transcriptome sequencing of a $P$. cubensis isolate infecting the susceptible cucumber cultivar Vlaspik revealed 2,383 genes that were differentially expressed in sporangia versus lesions in cucumber leaves (Savory et al. 2012b). In a related study, transcriptome analysis of the cucumber cultivar Vlaspik infected by $P$. cubensis showed differential expression of 15,286 cucumber genes in infected versus uninfected tissue (Adhikari et al. 2012). These studies have provided a solid foundation for using genomics and functional approaches in studying interactions of the $P$. cubensis-cucumber pathosystem. Nonetheless, given the diversity of cucurbit hosts that $P$. cubensis is able to infect, whole-genome sequencing data of additional $P$. cubensis isolates will be a key to characterize the genetic diversity of pathogen populations and host-pathogen interactions. Efforts to sequence additional $P$. cubensis isolates from diverse cucurbit hosts using Illumina next generation sequencing are underway (Withers et al. 2014). Sequencing of diverse isolates of Pseudoperonospora humuli, the causal agent of hop downy mildew and other "sister species" of P. cubensis, is also in progress (Withers et al. 2014). In combination, these data will provide resources needed for comparative genomics to address questions about host specificity and pathogen adaptation, which could significantly accelerate breeding efforts. In the last few years, reference genomes for cucumber (Huang et al. 2009), melon (Garcia-Mas et al. 2012), and watermelon (Guo et al. 2013) have been published, and other cucurbit genomes are currently being sequenced, which have increased our understanding of genetic diversity and allowed the identification of markers for genomicsassisted breeding.

\section{DYNAMICS IN EUROPEAN POPULATIONS}

Historical aspects. $P$. cubensis exists in Europe since the beginning of the 20th century (Lebeda 1991; Skalický 1961). It was introduced into Europe before 1902 via the territory of Russia (Rostowzew, 1903), probably from Japan (first recorded in 1889) and Indonesia (first recorded around 1900) (Zimmermann, 1909).

During the first decades of the 20th century, the occurrence of the pathogen was reported from various European countries (e.g., Austria, England, France, Germany, Hungary, the Czech Republic, Italy, the Netherlands, and former Yugoslavia) (Lebeda 1986a, b; Smolák 1927; Skalický 1961). It was most frequently detected on cucumbers grown under cover (Skalický 1961). In some European countries, $P$. cubensis was not considered an important pathogen of cucurbit crops, and was not even mentioned in most plant pathology textbooks published at that time (e.g., Čača 1981). The first epidemic distribution of $P$. cubensis in Central Europe occurred in the second half of the 1980s (Lebeda 1986a, b; Lebeda and Schwinn 1994). The first epidemics occurred in summer 1984 on cucumbers and partly on melon, primarily in Southern Slovakia (Zacha et al. 1985), Moravia and areas surrounding Prague (Lebeda 1986a, b). The damage to cucumbers was moderate due to the late appearance of the disease (Lebeda 1986a, b; Zacha et al. 1985). A year later, epidemics were extremely devastating with an estimated yield loss in cucumbers of 80 to $90 \%$ (Lebeda 1991). In early August 1985, the entire territory of Czechoslovakia had been affected by the epidemic (Lebeda 1986a, b). Similar severe epidemics occurred in 1986 to 1988 with limited losses, however, losses increased to more than $80 \%$ in 1989 (Lebeda 1991).

In 1985, strong epidemics were observed in cucumber all over Europe (Czech Republic, Austria, Poland, Denmark, England, France, Germany, Switzerland, Hungary, Yugoslavia, Bulgaria, Romania, Moldova, Ukraine, and Belarus) (Lebeda 1990; Lebeda and Cohen 2011; Lebeda and Schwinn 1994). Sporangia were distributed via air streams probably from Poland to Finland (Tahvonen 1985), Sweden (Forsberg 1986) and Norway (Sundheim and Hodnebrog 1987), where the disease was observed again recently (Nordskog et al. 2009). No disease occurred during that period in Central Europe on Cucumis melo or Cucurbita spp., neither in the field nor in the greenhouse (Lebeda and Gadasova 2002). Heavy epidemics repeatedly occurred on cucumbers in the following two decades, as in many other parts of the world (e.g., in Israel, Japan, India) (Lebeda and Cohen 2011). The disease in Central and Northern Europe was considered to be the consequence of pathogen spread from Hungary and southern Europe via South Slovakia to South and Central Moravia and later to East and Central Bohemia (Lebeda 1986a, 1990). Serious infections were reported in the following years (Lebeda and Schwinn 1994; Lebeda et al. 2011). From 2009 onwards, new outbreaks of downy mildew in Central Europe caused serious damages to also other cucurbits (Cucumis melo, Cucurbita spp., Citrullus lanatus, and Lagenaria sp.) (Lebeda and Cohen 2011; Lebeda et al. 2011, 2013a, b; Pavelková et al. 2011), most likely resulting from genetic changes in virulence structure of $P$. cubensis populations (Lebeda et al. 2012, 2013a, b, 2014). Recently, some information on spatial distribution, host range, population changes in specific geographic regions, virulence and genetic variation of European $P$. cubensis populations have been reported (Lebeda et al. 2010; 2014).

Changes in disease severity and host range. Disease prevalence and severity as well as host range have been evaluated in Central Europe since 2001. The geographical distribution of P. cubensis was assessed in more detail at 80 to 100 locations per year in two main regions of the Czech Republic (Lebeda et al. 2011, 2014). Heavy leaf infections were primarily observed on cucumber toward the end of the growing season (second half of August) across all areas of the Czech Republic, with some year to year fluctuations. Similar outbreaks were recorded in the surrounding countries (Austria, Germany, Poland, and Slovakia). During 2001 to 2008, disease was rarely observed on melon (Cucumis melo) or Cucurbita moschata (Lebeda et al. 2011). A sudden change occurred in 2009, when new pathotypes attacked new hosts which have never been attacked: Cucurbita moschata (Pavelková et al. 2011), C. maxima, C. pepo, and Citrullus lanatus (Lebeda et al. 2011, 2012, 2013a).

Pathotype structure. Virulence studies conducted with 398 isolates collected during 2001 to 2010 revealed the presence of 67 pathotypes (classified according to Lebeda and Widrlechner 2003). The number of pathotypes recorded ranged from 33 (in 2001) to 5 (in 2007). Pathotypes 15.14 .10 and 15.14 .11 were the most frequent. One pathotype (15.15.15) named "super pathotype", was able to infect the whole set of 12 differentials. It was detected in 2001, 2003, 2004, and especially in 2008 and 2010 (Lebeda et al. $2013 \mathrm{~b}, 2014)$. At the isolate level, $73.4 \%$ of the virulence variation was represented by 11 P. cubensis pathotypes (Lebeda et al. 2013b). Eleven unique isolates, originating from Cucumis melo, Cucurbita pepo, C. maxima, C. moschata, and Citrullus lanatus, sampled in 2009 and 2010, belonged to seven different pathotypes (Lebeda et al. 2013b). Two of them (4.15.0 and 15.6.0) were unique in the entire study period (Lebeda et al. 2012, 2013a, b). A gradual increase in virulence evolved from 2001 to 2009 (Lebeda et al. 2010, 2013a). New pathotypes, able to infect Cucurbita spp., Citrullus lanatus, and Lagenaria siceraria under field conditions, have evolved since 2009 (Lebeda et al. 2011, 2012, 2013a, b, 2014). Recent analyses with molecular markers confirmed changes in the population (Kitner et al. 2015; Lebeda et al. 2013a, 2014). 
Genetic variation in populations. A set of 30 P. cubensis isolates was analyzed with amplified fragment length polymorphism technology (Lebeda and Gadasova 2002; Lebeda et al. 2013b) and a larger set of 64 isolates was used for multilocus sequencing analyses (Kitner et al. 2014). The isolates were collected during 1995 to 2012 in the Czech Republic (Lebeda and Gadasova 2002; Lebeda et al. 2013b, 2014) and supplemented by a subset of isolates from Runge et al. (2011). A total of 385 fragments were detected with 13 selective primer combinations, with 304 segregating (78.9\%) and 187 polymorphic fragments (48.6\%) (polymorphism at 1 and 5\% levels). The genetic relatedness of isolates was analyzed in a principal coordinate analysis.

Coclustering was apparent in isolates collected in 2009. They were clearly out-grouped from isolates collected from 1995 to 2008. However, no clustering was observed based on geographical origin or pathotype code (Kitner et al. 2015; Lebeda et al. 2014). Preliminary sequencing data revealed differences and changes in the genetic background between isolates sampled before and isolates sampled after 2009. All isolates of P. cubensis sampled before 2009 exhibited the pre-epidemic genotype of Clade II, which is probably indigenous to East Asia, whereas Clade I ( $P$. cubensis sensu stricto) was observed among isolates sampled from 2009 onwards (Fig. 5). In addition, over $60 \%$ of the post-2009 samples from Clade II had two heterozygous positions in the nrITS sequence, providing a hint for sexual reproduction (Kitner et al. 2015; Lebeda et al. 2014).

\section{CHEMICAL CONTROL AND FUNGICIDE RESISTANCE}

Although some information is available on "alternative" control methods of $P$. cubensis including biological control through mycoparasites or plant extracts (Scherf et al. 2010), host resistance (described above) and chemical control remain the major and most reliable measures for downy mildew control under field conditions.

Oomycete fungicides. A total of 16 chemical groups with different modes of action are available for the control of oomycete plant diseases. The most important single-site inhibitors are the phenylamides (PAs), quinone outside inhibitors (QoIs) and carboxylic acid amides (CAAs). The multisite inhibitors include dithiocarbamates (e.g., mancozeb), phthalimides (e.g., folpet), chlorothalonil, copper and sulfur formulations; cymoxanil, fosetyl$\mathrm{Al}$, fluazinam, quinone inside respiration inhibitors (QiIs, like cyazofamid), fluopicolide and ethaboxam (inhibiting beta-tubulin assembly) (Gisi and Sierotzki 2014). Older products which are still in use are hymexazol (heteroaromatics), fentin-acetate (organotins), etridiazole (thiadiazoles), propamocarb (carbamates) and the plant defense inducer acibenzolar-S-methyl (Bion). Two novel compounds became available recently: ametoctradin (quinone inhibitor at unknown site, QoSI; Gold et al. 2011) and oxathiapiprolin (inhibitor of oxysterol-binding protein; Sweigard et al. 2014). Resistance has developed to single-site fungicides in many oomycete plant pathogens, including $P$. cubensis. Isolates resistant to mefenoxam, strobilurins (Thornton et al. 2005) and fluopicolide were found in U.S. fields (Adams and Quesada-Ocampo 2014; Hausbeck and Linderman 2014). Resistance was also reported to cymoxanil and propamocarb (Hübschova and Lebeda 2010), but not to fosetyl-Al (Pavelkova et al. 2014).

Phenylamides. Phenylamides, mainly metalaxyl and its active isomer mefenoxam (Hermann and Gisi 2012), inhibit ribosomal RNA synthesis in Oomycetes (Fisher and Hayes 1982), affecting polymerase I complex of rRNA synthesis (Davidse 1995). PAs are highly active and specifically control oomycetes plant pathogens including downy mildews caused by Peronosporales and Sclerosporales and most members of the Pythiales and Saprolegniales (Gisi 2002). The long-lasting preventative activity, high mobility in plants, curative potential and excellent crop safety make PAs a valuable tool for disease control in many crops (Müller and Gisi 2012). They are used mostly as coformulated products with multisite fungicides or unrelated single-site inhibitors to broaden spectrum activity and reduce resistance build-up. Resistant isolates of Phytophthora infestans appeared in Israel and Europe soon after first introduction of metalaxyl (Gisi and Cohen 1996) and subsequently in most countries around the globe (FRAC list of resistant pathogenic organisms 2014, www.frac.info). Resistance in Plasmopara viticola was detected in 1981 in treated (Staub and Sozzi 1981) and untreated (Bosshard and Schüepp 1983) vineyards and later in many other countries (Gisi 2002; Gisi and Sierotzki 2008). Resistance to PAs in P. cubensis, was discovered two years after introduction of metalaxyl in Israel (Reuveni et al. 1980) and thereafter in other countries (Lebeda and Cohen 2012; Pavelkova et al. 2014).

Despite extensive research with PAs, the putative resistance gene(s) and site of mutation(s) have not been elucidated until recently (Müller and Gisi 2012). Davidse (1988) assumed that a mutation in the RNA polymerase gene is responsible for resistance. This was confirmed by Whisson et al. (2011) who identified a specific genomic region in a resistant $P$. infestans isolate encoding the large subunit of RNA polymerase I that, when transferred into a sensitive isolate, made it resistant. The mutation responsible for resistance was identified as Y382F in the RNApolI gene. Because it showed an association with $85 \%$ of the mefenoxam-resistant field isolates (Randall et al. 2014) a mutation in another gene, associated or not with Y382A, or additional genes/mechanisms may be also involved in PA resistance (Judelson and Roberts 1999). PA resistance in P. infestans is inherited as a monogenic trait (Shattock 1986, 1988) controlled by an incompletely dominant gene (Shaw and Shattock 1991). Similar mode of inheritance was obtained with $P$. capsici (Lucas et al. 1990), P. sojae (Bhat et al. 1993), and B. lactucae (Crute and Harrison 1988). Crossing sensitive and resistant field isolates of either P. infestans or P. viticola (Gisi and Sierotzki 2008) yielded $\mathrm{F} 1$ progeny isolates that were exclusively intermediate in sensitivity. The F2 progeny of $P$. viticola deviated from the expected Mendelian segregation (s:i:r = 1:2.7:2, instead of 1:2:1; Gisi et al. 2007), suggesting that multiple mechanisms may be involved in PA resistance. No inheritance studies were reported for $P$. cubensis.

Migration can introduce new genotypes including PA resistant individuals to new locations where by local selection may lead to dominance of new resistant clones. The appearance of new genotypes and changes in resistance frequencies may be also caused by sexual recombination - including in P. cubensis. A broad PA sensitivity distribution from highly sensitive to fully resistant isolates was found among 49 P. cubensis isolates collected during 2008 to 2011 in Europe, Israel and the United States (Hermann et al. 2014). Most isolates from Israel and the United States were resistant. Also, isolates collected in China during 2011 to 2012, Vietnam in 2013 and India in 2014, were mostly resistant to mefenoxam (Syngenta unpublished data). Although varying frequencies of PA

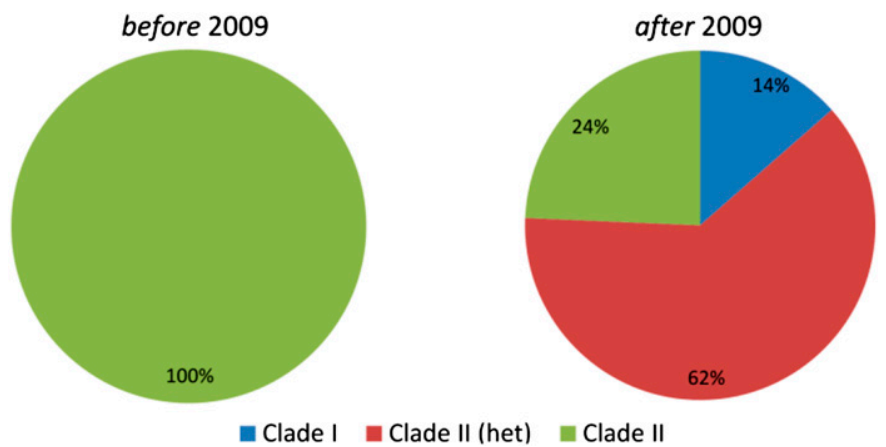

Fig. 5. Changes in Czech population of Pseudoperonospora cubensis. Isolates were sampled before and after 2009. Isolates with heterozygous single nucleotide polymorphisms in internal transcribed spacer region are designated as Clade II (het) (Lebeda et al. 2014). 
resistant isolates were detected in the Czech Republic between 2005 to 2009, a large part of the populations was still sensitive (Lebeda and Cohen 2012; Pavelkova et al. 2014). The use recommendations for PA-based products issued by FRAC (2014) include a preventive (not eradicative) use, always in mixture with unrelated effective (residual) products, at intervals not exceeding 14 days (or less when disease pressure is high). The number of PA applications per season is limited to two to four per crop a year or less if resistance is already established. PA should be integrated in a spray program early in the season or during the period of active vegetative growth of the crop.

Quinone outside respiration inhibitors. A few QoIs molecules are active against oomycete pathogen: azoxystrobin, famoxadone, and fenamidone. QoI fungicides are inhibitors of mitochondrial respiration, interrupting electron transport in cytochrome b (complex III) by binding to the Qo site, the ubiquinol oxidizing pocket which is located at the positive, outer side of mitochondrial membranes (Gisi et al. 2002). The cytochrome $\mathrm{b}(c y t b)$ gene, encoding the target protein for QoI binding, is located in the mitochondrial genome. Sierotzki and coworkers (Sierotzki et al. 2000a, 2000b) detected a G143A substitution (exchange of glycine by alanine at position 143 in the $c y t b$ gene) in QoI resistant ascomycete plant pathogens. It was then detected in resistant isolates of many plant pathogen including $P$. viticola and $P$. cubensis (Heaney et al. 2000, FRAC list of resistant pathogenic organisms 2014, www.frac.info). The mutation leads to a complete loss of disease control if QoIs are used as solo products. A second mutation, F129 L (exchange of phenylalanine by leucine at position 129) was discovered in resistant isolates of $P$. viticola (Sierotzki et al. 2005) and Pythium aphanidermatum (Olaya et al. 2003) resulting in "partial" resistance leading to reduced disease control.

The G143A mutation in populations of $P$. viticola was quickly selected through the continuous use of QoI's (Gisi and Sierotzki 2008). QoI resistant $P$. cubensis isolates (carrying G143A mutation) were first detected in Japan by Takeda et al. (1999) and Heaney et al. (2000) and confirmed by Ishii et al. (2001; 2002). Hence, solo use of QoI against cucumber downy mildew was dismissed or no longer recommended. Nevertheless, resistance frequencies remained high in many locations (Lebeda and Cohen 2012), especially in the East coast of the United States (QoI FRAC working group minutes, 2014, www.frac.info). In Japan, resistance declined a few years after QoIs use was dismissed (Ishii et al. 2001). In grape and cucurbit downy mildew populations, resistance frequencies remained rather high at certain locations; as a consequence QoIs are applied only in mixture with unrelated partner fungicides, and the number of applications per season and crop is limited.

Carboxylic acid amide fungicides. The CAA fungicides include three subclasses, the cinnamic acid amides (dimethomorph, flumorph, and pyrimorph), valinamide carbamates (benthiavalicarb, iprovalicarb, and valiphenalate), and mandelic acid amides (mandipropamid) (Gisi et al. 2012). CAAs exhibit specific activity against most oomycetes including pathogens of the Peronosporales such as $P$. viticola, B. lactucae, Peronospora spp., P. cubensis, and Phytophthora species in various crops. However, the genus Pythium and oomycetes other than Peronosporales are insensitive. Recent studies performed with mandipropamid elucidated the mode of action of CAA fungicides in $P$. infestans. The incorporation of ${ }^{14} \mathrm{C}$-labeled glucose into the $\beta-1,4$ glucan (cellulose) fraction of cell walls of germinating cystospores was inhibited in the presence of mandipropamid (Blum et al. 2010a). Gene sequencing of artificially generated resistant mutants revealed an amino acid substitution in the cellulose synthase CesA3 gene at position 1105 , from glycine to alanine or valine, G1105A/V. In addition, the transformation and expression of a mutated CesA 3 allele into a sensitive isolate resulted in CAA-resistant phenotype (Blum et al. 2010a). Thus, cellulose synthase is the primary target enzyme for CAA activity.

F1 progeny isolates, obtained from sexual crosses between CAA sensitive (homozygous AA) and CAA resistant (homozygous aa) isolates of $P$. viticola, were all sensitive to CAAs (Gisi et al. 2007). The segregation in the F2 progeny was about 4s:1r (Blum et al. 2010b) suggesting that resistance to CAAs (to all three classes) is inherited by one recessive nuclear gene (Gisi et al. 2007). Inheritance of SNPs in F1-, F2-, and F3-progeny isolates revealed resistance to be correlated with one specific SNP located in the CesA3 gene. When present in both alleles, this SNP led to the substitution of glycine for serine at position 1105 (G1105S), thus conferring CAA resistance (Blum et al. 2010b). The results demonstrate that resistance to CAAs in $P$. viticola was controlled by one recessive mutation in the CesA3 gene. Recent studies revealed that most CAA resistant $P$. viticola field isolates carry the G1105S mutation, but rarely another mutation G1105V (glycine for valine) was also present (Sierotzki et al. 2011). In P. cubensis, resistance was associated with two different amino acid exchanges: one at position $\mathrm{G} 1105 \mathrm{~V}$ (glycine for valine, in Israeli isolates mainly from cucumber) and the other G1105W (glycine for tryptophan, in U.S. isolates from cucumber, watermelon, zucchini or cantaloupe) (Blum et al. 2011; Sierotzki et al. 2011). Both mutations confer resistance to all CAA fungicides (Sierotzki et al. 2011). Resistance of $P$. cubensis to CAAs was reported in the Western coast in the United States, Israel, and China (CAA FRAC working group, www.frac.info; Zhu et al. 2007). Isolates collected in South Vietnam from cucumber and Lagenaria and in Russia from different cucurbit hosts were all sensitive to CAAs (Syngenta internal data 2013). The intrinsic risk and extent of resistance against CAAs in $P$. viticola and $P$. cubensis was classified by FRAC as moderate. As a consequence, CAAs are recommended only in mixtures with multisite fungicides or other effective noncross resistant partner fungicides. In Europe, a maximum of four treatments (three when high disease pressure) during one season may contain a CAA fungicide which should be used in a preventative manner.

\section{PROSPECTS}

Substantial knowledge has accumulated in the past decade on the population biology, epidemiology, genetics and genomics of $P$. cubensis. Nevertheless, large gaps still prevail in our understanding of the reasons responsible for the resurgence of this pathogen in many regions of the world. Among the major changes and recent discoveries are (i) the appearance of new aggressive races in the United States; (ii) the appearance of new pathotypes in Israel and Europe; (iii) the appearance of a new, A2, mating types in Israel, the United States, Asia and Europe (China, Vietnam, Russia, Ukraine, Kenya, Angola, India, France, and Germany); (iv) the capability of oospores to cause infections under laboratory and field conditions; (v) the ability of the pathogen to be also fruit- and seedborne. These new features, together with the continuous buildup and persistence of subpopulations resistant to various fungicides (PAs, QoIs, and CAAs) make the control of downy mildew in cucurbits even more complex. Possible reasons for the abovementioned global changes in P. cubensis populations are: (i) trade of fruits and seeds carrying inoculum and other man-aided distribution of new P. cubensis genotypes around the globe; (ii) long distance migration of sporangia by wind, birds and other carriers, e.g., from Southern to Northern states in the United States and possibly from East Africa along the East African-Syrian rift to Israel; (iii) mating between $\mathrm{A} 1$ and $\mathrm{A} 2$ isolates to produce offspring progeny with enhances aggressiveness and expanded host range. We lack information on various additional important aspects in the biology of $P$. cubensis including: (i) the mode of inheritance of pathogenicity (host range), mating type and resistance to fungicides; (ii) the population structure (genotype distribution) in various countries; (iii) oospore survival, germination, and infectivity; oospore role as initial inoculum; (iv) molecular tools and investigations to better diagnose the pathogen and its movement around the globe; (v) the molecular basis for host specificity; 
(vi) fitness and competitiveness of races, pathotypes and mating types. When these gaps are filled, our ability to develop better control strategies of $P$. cubensis will be much improved.

\section{ACKNOWLEDGMENTS}

Research in the Quesada laboratory is supported by Pickle Packers International (PPI), the U.S. Department of Agriculture (USDA), Animal and Plant Health Inspection Service (APHIS), Award 13-8130-0254-CA, the USDA North Carolina Department of Agriculture (NCDA), Specialty Crop Block Grant Program (SCBGP), Award 12-25-B-16-88, and USDA project number NC02418.

\section{LITERATURE CITED}

Adams, M. L., and Quesada-Ocampo, L. M. 2014. Evaluation of fungicides for control of downy mildew on cucumber, Kinston 2013. Plant Dis. Manage. Rep. 8:V240.

Adhikari, B. N., Savory, E. A., Vaillancourt, B., Childs, K. L., Hamilton, J. P., Day, B., and Buell, C. R. 2012. Expression profiling of Cucumis sativus in response to infection by Pseudoperonospora cubensis. PLoS One 7:e34954.

Angelov, D. 1994. Inheritance of resistance to downy mildew, Pseudoperonospora cubensis (Berk. \& Curt.) Rostow. Rep. 2nd Natl. Symp. Plant Immunity. (Plovdiv) 3:99-105.

Angelov, D., Georgiev, P., and Krasteva, L. 2000. Two races of Pseudoperonospora cubensis on cucumbers in Bulgaria. In: Proc. Cucurbitaceae. N. Katzir and H. S. Paris, eds. ISHS Press, Ma'ale Ha Hamisha, Israel.

Arauz, L. F., Neufeld, K. N., Lloyd, A. L., and Ojiambo, P. S. 2010. Quantitative models for germination and infection of Pseudoperonospora cubensis in response to temperature and duration of leaf wetness. Phytopathology 100:959-967.

Badr, L. A. A., and Mohamed, F. G. 1998. Inheritance and nature of resistance to downy mildew disease in cucumber (Cucumis sativus L.). Ann. Agric. Sci. Moshtohor. 36:2517-2544. (in Arabic)

Bai, Z., Yuan, X., Cai, R., Liu, L., He, H., Zhou, H., and Pan, J. 2008. QTL analysis of downy mildew resistance in cucumber. Prog. Natl. Sci. 18: 706-710. (in Chinese)

Bains, S. S., and Sharma, N. K. 1986. Differential response of certain cucurbits to isolates of Pseudoperonospora cubensis and characteristics of identified races. Phytophylactica 18:31-33.

Bains, S. S., Sokhi, S. S., and Jhooty, S. H. 1977. Melothria maderaspatana, a new host of Pseudoperonospora cubensis. Indian J. Mycol. Plant Pathol. $7: 86$

Barnes, W. C. 1948. The performance of Palmetto, a new downy mildew resistant cucumber variety. Proc. Am. Soc. Hortic. Sci. 51:437-441.

Barnes, W. C. 1955. They both resist downy mildew: Southern cooperative trials recommend two new cucumbers. Seedsmans Dig. 14:46-47.

Barnes, W. C., Clayton, C. N., and Jenkins, J. M. 1946. The development of downy mildew-resistant cucumbers. Proc. Am. Soc. Hortic. Sci. 47:357-60.

Barnes, W. C., and Epps, W. M. 1954. An unreported type of resistance to cucumber downy mildew. Plant Dis. Rep. 38:620.

Barnes, W. C., and Epps, W. M. 1955. Progress in breeding cucumbers resistant to anthracnose and downy mildew. Proc. Am. Soc. Hortic. Sci. 65: 409-15.

Bedlan, G. 1989. First detection of oospores of Pseudoperonospora cubensis (Berk. et Curt.) Rost. on glasshouse cucumbers in Austria. Pflanzenschutzberichte 50:119-120. (in German with English Summary)

Bhat, R. G., McBlain, B. A., and Schmitthenner, A. F. 1993. The inheritance of resistance to metalaxyl and to fluorophenylalanine in matings of homothallic Phytophthora sojae. Mycol. Res. 97:865-870.

Blum, M., Boehler, M., Randall, E., Young, V., Csukai, M., Kraus, S., Moulin, F., Scalliet, G., Avrova, A. O., Whisson, S. C., and Fonné-Pfister, R. 2010a. Mandipropamid targets the cellulose synthase-like PiCesA3 to inhibit cell wall biosynthesis in the oomycete plant pathogen Phytophthora infestans. Mol. Plant Pathol. 11:227-243.

Blum, M., Waldner, M., and Gisi, U. 2010b. A single point mutation in the novel PvCesA3 gene confers resistance to the carboxylic acid amide fungicide mandipropamid in Plasmopara viticola. Fungal Genet. Biol. 47: 499-510.

Blum, M., Waldner, M., Olaya, G., Cohen, Y., Gisi, U., and Sierotzki, H. 2011. Resistance mechanism to carboxylic acid amid (CAA) fungicides in the cucurbit downy mildew pathogen Pseudoperonospora cubensis. Pest Manag. Sci. 67:1211-1214.

Bosshard, E., and Schüepp, H. 1983. Variability of selected strains of Plasmopara viticola with respect to their metalaxyl sensitivity under field conditions. Z. Pflkrank. Pflschutz. 90:449-459. (in German with English Summary)
Burkhardt, A., and Day, B. 2014. A transcriptomic approach to analyzing genetic pathways involved in Cucumis sativus resistance to Pseudoperonospora cubensis. Pages 1-3 in: Cucurbitaceae 2014 Proceedings. M. Havey, Y. Weng, B. Day, and R. Grumet, eds. American Society for Horticultural Science, Alexandria, VA.

Čača, Z. 1981. Zemědělská Fytopatologie. Z. Čača, ed., Státní zemědělské nakladatelství, Praha.

Call, A. D. 2012. Inheritance of resistance to downy mildew in cucumber (Cucumis sativus L.) PI 197088 and effect of interaction of host plant resistance, fungicides, and environment on severity of downy mildew on cucumber. Ph.D. North Carolina State University, Raleigh, NC.

Call, A. D., Criswell, A. D., Wehner, T. C., Ando, K., and Grumet, R. 2012a. Resistance of cucumber cultivars to a new strain of cucurbit downy mildew. Hortic. Sci. 47:171-178.

Call, A. D., Criswell, A. D., Weimer, T. C., Klosinska, U., and Kozik, E. U. 2012b. Screening cucumber for resistance to downy mildew caused by Pseudoperonospora cubensis (Berk. and Curt.) Rostov. Crop Sci. 52: 577-592.

Cappelli, C., Buonaurio, R., and Stravato, V. M. 2003. Occurrence of Pseudoperonospora cubensis pathotype 5 on squash in Italy. Plant Dis. 87:449.

Cespedes-Sanchez, M. C., Naegele, R. P., Kousik, C. S., and Hausbeck, M. K. 2015. Field response of cucurbit hosts to Pseudoperonospora cubensis in Michigan. Plant Dis.

Chen, T., and Cohen, Y. 2013. Isolate-dependent inheritance of resistance to downy mildew in cucumber. Phytoparasitica 41:462.

Cohen, Y. 1977. The combined effects of temperature, leaf wetness and inoculum concentration on infection of cucumbers with Pseudoperonospora cubensis. Can. J. Bot. 55:1487.

Cohen, Y., Meron, I., Mor, N., and Zuriel, S. 2003. A new pathotype of Pseudoperonospora cubensis causing downy mildew in cucurbits in Israel. Phytoparasitica 31:458-466.

Cohen, Y., and Rotem, J. 1969. The effects of lesion development, air temperature and duration of moist periods on sporulation of Pseudoperonospora cubensis in cucumbers. Isr. J. Bot. 18:135-140.

Cohen, Y., and Rubin, A. E. 2012. Mating type and sexual reproduction of Pseudoperonospora cubensis, the downy mildew agent of cucurbits. Eur. J. Plant Pathol. 132:577-592.

Cohen, Y., Rubin, A. E., and Galperin, M. 2011. Formation and infectivity of oospores of Pseudoperonospora cubensis, the causal agent of downy mildew in cucurbits. Plant Dis. 95:874.

Cohen, Y., Rubin, A. E., and Galperin, M. 2013a. Host preference of mating type in Pseudoperonospora cubensis, the downy mildew causal agent of cucurbits. Plant Dis. 97:292-292.

Cohen, Y., Rubin, A. E., Galperin, M., Ploch, S., Runge, F., and Thines, M. 2014. Seed transmission of Pseudoperonospora cubensis. PLoS One 9: e109766.

Cohen, Y., Rubin, A. E., Liu, X. L., Wang, W. Q., Zhang, Y. L., and Hermann, D. 2013b. First report on the occurrence of A2 mating type of the cucurbit downy mildew agent Pseudoperonospora cubensis in China. Plant Dis. 97: 559.

Cohen, Y., and Samoucha, Y. 1984. Cross-resistance to four systemic fungicides in metalaxyl-resistant strains of Phytophthora infestans and Pseudoperonospora cubensis. Plant Dis. 68:137-139.

Colucci, S. J. 2008. Host Range, Fungicide Resistance and Management of Pseudoperonospora cubensis, Causal Agent of Cucurbit Downy Mildew. Department of Plant Pathology, North Carolina State University, Raleigh, NC.

Colucci, S. J., Wehner, T. C., and Holmes, G. J. 2006. The downy mildew epidemic of 2004 and 2005 in the eastern United States. In: Proc. Cucurbitaceae 2006. G. J. Holmes, ed. Universal Press, Raleigh, NC.

Criswell, A. D. 2008. Screening for Downy Mildew Resistance in Cucumber. North Carolina State University, Raleigh, NC.

Crute, I. R., and Harrison, J. M. 1988. Studies on the inheritance of resistance to metalaxyl in Bremia lactucae and on the stability and fitness of field isolates. Plant Pathol. 37:231-250.

D'Ercole, N. 1975. La peronospora del cetrioloin coltura protetta. Infitore Fitopatol. 25:11-13.

Davidse, L. C. 1988. Phenylamide fungicides: Mechanism of action and resistance. In: Fungicide Resistance in North America. C. J. Delp, ed. American Phytopathological Society, St Paul, MN.

Davidse, L. C. 1995. Phenylamide fungicides: Biochemical action and resistance. In: Modern Selective Fungicides, 2nd ed., H. Lyr, ed. Gustav Fischer, Jena, Germany.

Ding, G., Qin, Z., Zhou, X., and Fan, J. 2007. RAPD and SCAR markers linked to downy mildew resistance genes in cucumber. Acta Bot. BorealiOccident. Sin. 27:1747-1751. (in Chinese)

Doran, W. L. 1932. Downy mildew of cucumbers. Mass Agr. Exp. St. Re. B. 283:1-22.

Doruchowski, R. W., and Łazokowska-Ryk, E. 1992. Inheritance of resistance to downy mildew (Pseudoperonospora cubensis Berk. \& Curt.) in Cucumis 
sativus. In: Proc. V Eucarpia Cucurbitaceae Symp. R. W. Doruchowski. ed. Skierniewice-Warszawa, Poland.

El-Hafaz, A., El-Din, B., El-Doweny, H. H., and Awad, M. M. W. 1990. Inheritance of downy mildew resistance and its nature of resistance in cucumber. Ann. Agric. Sci. Moshtohor 28:1681-1697.

Epps, W. M., and Barnes, W. C. 1952. The increased susceptibility of the palmetto cucumber to downy mildew in South Carolina. Plant Dis. Rep. 36: 14-15.

Falach, L. 2014. Biology and genetics of mating type and fungicide resistance in Pseudoperonospora cubensis. The Mina \& Everard Goodman Faculty of Life Sciences, Bar Ilan University, Ramat-Gan, Israel. (in Hebrew with English Summary)

Fanourakis, N. E., and Simon, P. W. 1987. Analysis of genetic linkage in the cucumber. J. Hered. 78:238-242.

Fisher, D. J., and Hayes, A. L. 1982. Mode of action of the fungicides furalaxyl, metalaxyl and ofurace. Pestic. Sci. 13:330-339.

Forsberg, A. S. 1986. Downy mildew-Pseudoperonospora cubensis in Swedish cucumber fields. Vaxtskyddsnotiser 50:17-19.

Fraymouth, J. 1956. Haustoria of the Peronosporales. Trans. Br. Mycol. Soc. 39:79-107.

Garcia-Mas, J., Benjak, A., Sanseverino, W., Bourgeois, M., Mir, G., Gonzalez, V. M., Henaff, E., Camara, F., Cozzuto, L., Lowy, E., Alioto, T., Capella-Gutierrez, S., Blanca, J., Canizares, J., Ziarsolo, P., Gonzalez-Ibeas, D., Rodriguez-Moreno, L., Droege, M., Du, L., Alvarez-Tejado, M., Lorente-Galdos, B., Mele, M., Yang, L., Weng, Y., Navarro, A., Marques-Bonet, T., Aranda, M. A., Nuez, F., Pico, B., Gabaldon, T., Roma, G., Guigo, R., Casacuberta, J. M., Arus, P., and Puigdomenech, P. 2012. The genome of melon (Cucumis melo L.). Proc. Natl. Acad. Sci. USA 109: $11872-11877$

Gisi, U. 2002. Chemical control of downy mildews. In: Advances in Downy Mildew Research. P. T. N. Spencer, U. Gisi, and A. Lebeda, eds. Kluwer Academic Publishers, Dordrecht, Netherlands.

Gisi, U., and Cohen, Y. 1996. Resistance to phenylamide fungicides: A case study with Phytophthora infestans involving mating type and race structure. Annu. Rev. Phytopathol. 34:549-572.

Gisi, U., Lamberth, C., Mehl, A., and Seitz, T. 2012. Carboxylic acid amide (CAA) fungicides. In: Modern Crop Protection Compounds, 2nd ed. W. Krämer, U. Schirmer, P. Jeschke, and M. Witschel, eds. Wiley-VCH, Weinheim, Germany.

Gisi, U., and Sierotzki, H. 2008. Fungicide mode of action and resistance in downy mildews. Eur. J. Plant Pathol. 122:157-167.

Gisi, U., and Sierotzki, H. 2014. Mechanisms of resistance: Oomycete fungicides phenylamides, quinone outside inhibitors and carboxylic acid amides. In: Fungicide Resistance in Plant Pathogens: Principles and a Guide to Practical Management. H. Ishii and D. Hollomon, eds. Springer, Japan.

Gisi, U., Sierotzki, H., Cook, A., and McCaffery, A. 2002. Mechanisms influencing the evolution of resistance to Qo inhibitor fungicides. Pest Manag. Sci. 58:859-867.

Gisi, U., Waldner, M., Kraus, N., Dubuis, P. H., and Sierotzki, H. 2007. Inheritance of resistance to carboxylic acid amide (CAA) fungicides in Plasmopara viticola. Plant Pathol. 56:199-208.

Gold, R. E., Schiffer, H., Speakman, J., Stammler, G., and Klappach, K., Brix, H. D., and Schlehuber, S. 2011. Initium - A new innovative fungicide for the control of oomycetes in specialty crops. Pages 55-61 in: Modern Fungicides and Antifungal Compounds VI. H. W. Dehne, H. B. Deising, U. Gisi, H. K. Kuck, P. E. Russell, and H. Lyr, eds. 16th Intl. Reinhardsbrunn Symp., DPG Spectrum Phytomedizin, Braunschweig, Germany.

Granke, L. L., and Hausbeck, M. K. 2011. Dynamics of Pseudoperonospora cubensis sporangia in commercial cucurbit fields in Michigan. Plant Dis. 95:1392-1400.

Guo, S., Zhang, J., Sun, H., Salse, J., Lucas, W. J., Zhang, H., Zheng, Y., Mao, L., Ren, Y., Wang, Z., Min, J., Guo, X., Murat, F., Ham, B. K., Zhang, Z., Gao, S., Huang, M., Xu, Y., Zhong, S., Bombarely, A., Mueller, L. A., Zhao, H., He, H., Zhang, Y., Huang, S., Tan, T., Pang, E., Lin, K., Hu, Q., Kuang, H., Ni, P., Wang, B., Liu, J., Kou, Q., Hou, W., Zou, X., Jiang, J., Gong, G., Klee, K., Schoof, H., Huang, Y., Hu, X., Dong, S., Liang, D., Wang, J., Wu, K., Xia, Y., Zhao, X., Zheng, Z., Xing, M., Liang, X., Huang, B., Lv, T., Yin, Y., Yi, H., Li, R., Wu, M., Levi, A., Zhang, X., Giovannoni, J. J., Li, Y., and Fei, Z. 2013. The draft genome of watermelon (Citrullus lanatus) and resequencing of 20 diverse accessions. Nat. Genet. 45:51-58.

Hausbeck, M. K., and Linderman, S. D. 2014. Evaluation of fungicides for control of downy mildew of cucumber, 2013. Plant Dis. Manag. Rep. 8:V304.

Heaney, S. P., Hall, A. A., Davies, S. A., and Olaya, G. 2000. Resistance to fungicides in the QoI-STAR cross-resistance group: Current perspectives. Proc. Brighton Crop Prot. Conf. 2:755-762

Hermann, D., and Gisi, U. 2012. Fungicide resistance in Oomycetes with special reference to Phytophthora infestans and phenylamides. In: Fungicide Resistance in Crop Protection. T. S. Thind, ed. CAB International, Oxfordshire, UK.
Hermann, D., McKenzie, D., Cohen, Y., and Gisi, U. 2014. Phenylamides: Market trends and resistance evolution for important Oomycete pathogens 35 years after the first product introduction. In: Fungicide Resistance Development in North America. K. L. Stevenson, C. A. Wyenandt, and M. L. McGrath, eds. American Phytopathological Society, St Paul, MN.

Hiura, M., and Kawada, S. 1933. On the overwintering of Peronoplasmopara cubensis. Jpn. J. Bot. 6:507-513.

Holdsworth, W. L., Summers, C. F., Glos, M., Smart, C. D., and Maxourek, M. 2014. Development of downy mildew-resistant cucumbers for late-season production in Northeastern United States. Hortic. Sci. 49:10-17.

Holmes, G. J., Main, C. E., and Zeever, Z. T. 2004. Cucurbit downy mildew: A unique pathosystem for disease forecasting. In: Advances in Downy Mildew Research. P. T. N. Spencer-Phillips and M. Jeger, eds. Kluwer Academic Publishers, Dordercht.

Holmes, G. J., Ojiambo, P. S., Hausbeck, M. K., Quesada-Ocampo, L., and Keinath, A. P. 2015. Resurgence of cucurbit downy mildew in the United States: A watershed event for research and extension. Plant Dis. 99: 428-441.

Holmes, G. J., Wehner, T. C., and Thornton, A. 2006. An old enemy reemerges. Am. Veg. Grow. February:14-15.

Horejsi, T., Staub, J., and Thomas, C. 2000. Linkage of random amplified polymorphic DNA markers to downy mildew resistance in cucumber (Cucumis sativus L.). Euphytica 115:105-113.

Huang, S., Li, R., Zhang, Z., Li, L., Gu, X., Fan, W., Lucas, W. J., Wang, X., Xie, B., Ni, P., Ren, Y., Zhu, H., Li, J., Lin, K., Jin, W., Fei, Z., Li, G., Staub, J., Kilian, A., Van der Vossen, E. A., Wu, Y., Guo, J., He, J., Jia, Z., Tian, G., Lu, Y., Ruan, J., Qian, W., Wang, M., Huang, Q., Li, B., Xuan, Z., Cao, J., Asan, Z., Wu, Z., Zhang, J., Cai, Q., Bai, Y., Zhao, B., Han, Y., Li, Y., Li, X., Wang, S., Shi, Q., Liu, S., Cho, W. K., Kim, J. Y., Xu, Y., Heller-Uszynska, K., Miao, H., Cheng, Z., Zhang, S., Wu, J., Yang, Y., Kang, H., Li, M., Liang, H., Ren, X., Shi, Z., Wen, M., Jian, M., Yang, H., Zhang, G., Yang, Z., Chen, R., Ma, L., Liu, H., Zhou, Y., Zhao, J., Fang, X., Fang, L., Liu, D., Zheng, H., Zhang, Y., Qin, N., Li, Z., Yang, G., Yang, S., Bolund, L., Kristiansen, K., Li, S., Zhang, X., Wang, J., Sun, R., Zhang, B., Jiang, S., and Du, Y. 2009. The genome of the cucumber, Cucumis sativus L. Nat. Genet. 41:1275-1281.

Hübschova, J., and Lebeda, A. 2010. Fungicide effectiveness on Czech populations of Pseudoperonospora cubensis. Acta Hortic. 871:458-464.

Hughes, M. B., and Van Haltern, F. 1952. Two biological forms of Pseudoperonospora cubensis. Plant Dis. Rep. 36:365-367.

Innark, P., Ratanachan, T., Khanobdee, C., Samipak, S., and Jantasuriyarat, C. 2014. Downy mildew resistant/susceptible cucumber germplasm (Cucumis sativus L.) genetic diversity assessment using ISSR markers. Crop Prot. 60:56-61.

Ishii, H., Fraaije, B. A., Sugiyama, T., Noguchi, K., Nishimura, K., Takeda, T., Amano, T., and Hollomon, D. W. 2001. Occurrence and molecular characterization of strobilurin resistance in cucumber powdery mildew and downy mildew. Phytopathology 91:1166-1171.

Ishii, H., Sugiyama, T., Nishimura, K., and Ishikawa, Y. 2002. Strobilurin resistance in cucumber pathogens: Persistence and molecular diagnosis of resistance. In: Modern Fungicides and Antifungal Compounds III. H. W. Dehne, U. Gisi, K. H. Kuck, P. E. Russell, and H. Lyr, eds. Proc. 13th Intl. Reinhardsbrunn Symp., Agro Concept, Bonn, Germany.

Iwata, Y. 1949. Studies on the invasion of cucumber plants by downy mildew. Ann. Phytopathol. Soc. Jpn. 13:60-61. (In Japanese, with English summary)

Judelson, H. S., and Roberts, S. 1999. Multiple loci determining insensitivity to phenylamide fungicides on Phytophthora infestans. Phytopathology 89: 754-760.

Kennard, W. C., Poetter, K., Dijkhuizen, A., Meglic, V., Staub, J. E., and Havey, M. J. 1994. Linkage among RFLP, RAPD, isozyme, disease resistance and morphological markers in narrow and wide crosses of cucumber. Theor. Appl. Genet. 89:42-48.

Kitner, M., Lebeda, A., Sharma, R., Runge, F., Dvořák, P., Tahir, A., Choi, Y.-J., Sedláková, B., and Thines, M. 2015. Coincidence of virulence shifts and population genetic changes of Pseudoperonospora cubensis in the Czech Republic. Plant Pathol.

Kozik, E. U., Klosinska, U., Call, A. D., and Wehner, T. C. 2013. Heritability and genetic variance estimates for resistance to downy mildew in cucumber access Ames 2354. Crop Sci. 53:177-182.

Lange, L., Eden, U., and Olson, L. W. 1989. Zoosporogenesis in Pseudoperonospora cubensis, the causal agent of cucurbit downy mildew. Nord. J. Bot. 8:497-504.

Langston, D. B., and Sanders, F. H. 2013. Evaluation of fungicides for control of downy mildew on cucumber in Georgia II, 2012. Plant Dis. Manage. Rep. 7:V109.

Lebeda, A. 1986a. Epidemic occurrence of Pseudoperonospora cubensis in Czechoslovakia. Temperate Downy Mildews Newsl. 4:15-17.

Lebeda, A. 1986b. Plíseň okurková a její epidemický výskyt v roce 1985 (Cucurbit downy mildew and its epidemic occurrence in 1985). Zahradnictvo 11:21-22. 
Lebeda, A. 1990. Biologie a ekologie plísně okurkové (Biology and ecology of cucurbit downy mildew). In: Plíseň okurková (Cucurbit downy mildew), ed. A. Lebeda. Praha, Ceskoslovenská vědecká společnost pro mykologii při ČSAV (Czechoslovak Scientific Society for Mycology by Czechoslovak Academy of Sciences).

Lebeda, A. 1991. Resistance in muskmelons to Czechoslovak isolates of Pseudoperonospora cubensis from cucumbers. Sci. Hortic. (Amsterdam) 45:255-260

Lebeda, A., and Cohen, Y. 2011. Cucurbit downy mildew (Pseudoperonospora cubensis)-Biology, ecology, epidemiology, host-pathogen interaction and control. Eur. J. Plant Pathol. 129:157-192.

Lebeda, A., and Cohen, Y. 2012. Fungicide resistance in Pseudoperonospora cubensis, the causal agent of cucurbit downy mildew. In: Fungicide Resistance in Crop Protection: Risk and Management. T. S. Thind, ed. CAB International, Wallinford, UK.

Lebeda, A., and Gadasova, V. 2002. Pathogenic variation of Pseudoperonospora cubensis in the Czech Republic and some other European countries. Acta Hortic. 588:137-141.

Lebeda, A., Hübschová, J., and Urban, J. 2010. Temporal population dynamics of Pseudoperonospora cubensis. Cucurbitaceae Proceedings. J. A. Thies, S. Kousik, and A. Levi, eds. American Society for Horticultural Science, Alexandria, VA.

Lebeda, A., Kitner, M., Sedláková, B., Sharma, R., Runge, F., and Thines, M. 2014. Biological and molecular evidences about changes in the host range and virulence of Pseudoperonospora cubensis populations in the Czech Republic. Pages 24-27 in: Cucurbitaceae 2014 Proceedings. M. Havey, Y. Weng, B. Day, and R. Grumeteds, eds. Michigan State University and University of Wisconsin-Madison, American Society for Horticultural Science, Alexandria, VA.

Lebeda, A., Pavelkova, J., Sedlakova, B., and Urban, J. 2013a. Structure and temporal shifts in virulence of Pseudoperonospora cubensis populations in the Czech Republic. Plant Pathol. 62:336-345.

Lebeda, A., Pavelkova, J., Urban, J., and Sedlakova, B. 2011. Distribution, host range and disease severity of Pseudoperonospora cubensis on cucurbits in the Czech Republic. J. Phytopathol. 159:589-596.

Lebeda, A., and Schwinn, F. J. 1994. The downy mildews-an overview of recent research progress. J. Plant Dis. Prot. 101:225-254.

Lebeda, A., Sedláková, B., and Pavelková, J. 2012. New hosts of Pseudoperonospora cubensis in the Czech Republic and pathogen virulence variation. In Cucurbitaceae 2012. N. Sari, I. Solmaz, and V. Aras, eds. Cukurova University. Proceedings of the Xth EUCARPIA Meeting on Genetics and Breeding of Cucurbitaceae. Antalya, Turkey.

Lebeda, A., Sedláková, B., Pavelková, J., and Kitner, M. 2013b. Changes in the host range and virulence variation of Pseudoperonospora cubensis populations in the Czech Republic. Acta Phytopathol. Sin. 43:18-19.

Lebeda, A., and Urban, J. 2004. Disease impact and pathogenicity variation in Czech populations of Pseudoperonospora cubensis. In: Progress in Cucurbit genetics and breeding research. Pages 267-273 in: Proc. Cucurbitaceae 2004, 8th EUCARPIA Meeting on Cucurbit Genetics and Breeding. A. Lebeda and H. S. Paris, eds. Palacky University, Olomouc, Czech Republic.

Lebeda, A., and Widrlechner, M. P. 2003. A set of Cucurbitaceae taxa for differentiation of Pseudoperonospora cubensis pathotypes. J. Plant Dis. Prot. 110:337-349.

Lucas, J. A., Greer, G., Oudemans, P. V., and Coffey, M. 1990. Fungicide sensitivity in somatic hybrids of Phytophthora capsici by protoplast fusion. Physiol. Mol. Plant Pathol. 36:175-187.

McDonald, B. A., and Linde, C. 2002. The population genetics of plant pathogen and breeding strategies for durable resistance. Euphytica 124: $163-80$.

McFerson, J. R. 1978. A screening procedure for determining levels of resistance in cucumber. MSc Thesis, Texas A\&M University, Texas.

Meglic, V., and Staub, J. E. 1996. Inheritance and linkage relationships of isozyme and morphological loci in cucumber (Cucumis sativus L.). Theor. Appl. Genet. 92:865-872.

Milus, E. A., Kristensen, K., and Hovmoller, M. S. 2009. Evidence for increased aggressiveness in a recent widespread strain of Puccinia striiformis f. sp. tritici causing stripe rust of wheat. Phytopathology 99:89-94.

Müller, U., and Gisi, U. 2012. Newest Aspects of Nucleic Acid Synthesis inhibitors: Metalaxyl-M. Modern Crop Protection Compounds, 2nd ed. W. Krämer, U. Schirmer, P. Jeschke, and M. Witschel, eds. Wiley-VCH, Weinheim, Germany.

Neufeld, K. N., and Ojiambo, P. S. 2012. Interactive effects of temperature and leaf wetness duration on sporangia germination and infection of cucurbit hosts by Pseudoperonospora cubensis. Plant Dis. 96:345-353.

Nordskog, B., Brurberg, M., Sivertsen, T., Gadoury, D., and Hermansen, A. 2009. Cucumber downy mildew epidemics in Norway. Can we blame our neighbors? In: Proc. 10th Intern. Epidemiology Workshop. R. Gadoury, M. C. Seem, and M. M. Moyer, eds. New York State Agricultural Experiment Station, Geneva, NY.
Ojiambo, P. S., and Holmes, G. J. 2011. Spatiotemporal spread of cucurbit downy mildew in the eastern United States. Phytopathology 101:451-461.

Ojiambo, P. S., Holmes, G. J., Britton, W., Keever, T., Adams, M. L., Babadoost, M., Bost, S. C., Boyles, R., Brooks, M., Damicone, J., Draper, M. A., Egel, D. S., Everts, K. L., Ferrin, D. M., Gevens, A. J., Gugino, B. K., Hausbeck, M. K., Ingram, D. M., Isakeit, T., Keinath, A. P., Koike, S. T., Langston, D., McGrath, M. T., Miller, S. A., Mulrooney, R., Rideout, S., Roddy, E., Seebold, K. W., Sikora, E. J., Thornton, A., Wick, R. L., Wyenandt, C. A., and Zhang, S. 2011. Cucurbit downy mildew ipmPIPE: A next generation web-based interactive tool for disease management and extension outreach. Online. Plant Health Prog.

Ojiambo, P. S., and Kang, E. L. 2013. Modeling spatial frailties in survival analysis of cucurbit downy mildew epidemics. Phytopathology 103:216-227.

Olaya, G., Cleere, S., Stanger, C., Burbidge, J., Hall, A., and Windass, J. 2003. A novel potential target site and QoI fungicide resistance mechanism in Pythium aphanidermatum. (Abstr.) Phytopathology 103:S67.

Palti, J., and Cohen, Y. 1980. Downy mildew of cucurbits (Pseudoperonospora cubensis)-The fungus and its hosts, distribution, epidemiology and control. Phytoparasitica 8:109-147.

Pang, X., Zhou, X., Wan, H., and Chen, J. 2013. QTL mapping of downy mildew resistance in an introgression line derived from interspecific hybridization between cucumber and Cucumis hystrix. J. Phytopathol. 161: 536-543.

Pappas, A. C. 1982. Metalaxyl resistance and control of cucumber downy mildew with oomycete fungicides. Ann. Benakeion Phytopathol. Instit. 13: 194-212.

Pavelkova, J., Lebeda, A., and Sedlakova, B. 2011. First report of Pseudoperonospora cubensis on Cucurbita moschata in the Czech Republic. Plant Dis. 95:878-879.

Pavelkova, J., Lebeda, A., and Sedlakova, B. 2014. Efficacy of fosetyl-Al, propamocarb, dimethomorph, cymoxanil, metalaxyl and metalaxyl-M in Czech Pseudoperonospora cubensis populations during the years 2005 through 2010. Crop Prot. 60:9-19.

Pershin, A. F., Medvedeva, N. I., and Nedvedev, A. V. 1988. Quantitative approach to studying the genetics of disease resistance. IV. Interaction of the genetic systems for resistance to powdery and downy mildews in cucumber. Geneticka USSR 24:484-493. (in Russian)

Petrov, L., Boodert, K., Sheck, L., Baider, A., Rubin, E., Cohen, Y., Datzir, N., and Paris, H. S. 2000. Resistance to downy mildew, Pseudoperonospora cubensis, in cucumbers. Acta Hortic. 510:203-209.

Picado, A., Guitian, F. J., and Pfeiffer, D. U. 2007. Space-time interaction as an indicator of local spread during the 2001 FMD outbreak in the UK. Prev. Vet. Med. 79:3-19.

Polat, I., Baysal, O., Mercati, F., Kitner, M., Cohen, Y., Lebeda, A., and Carimi, F. 2014. Characterization of Pseudoperonospora cubensis isolates from Europe and Asia using ISSR and SRAP molecular markers. Eur. J. Plant Pathol. 139:641-653.

Quesada-Ocampo, L. M., Granke, L. L., Olsen, J., Gutting, H. C., Runge, F., Thines, M., Lebeda, A., and Hausbeck, M. K. 2012. The genetic structure of Pseudoperonospora cubensis populations. Plant Dis. 96:1459-1470.

Randall, E., Young, V., Sierotzki, H., Scalliet, G., Birch, P. R. J., Cooke, D. E. L., Csukai, M., and Whisson, S. C. 2014. Sequence diversity in the large subunit of RNA polymerase I contributes to mefenoxam insensitivity in Phytophthora infestans. Mol. Plant Pathol. 15:664-676.

Reuveni, M., Eyal, H., and Cohen, Y. 1980. Development of resistance to metalaxyl in Pseudoperonospora cubensis. Plant Dis. 64:1108-1109.

Robinson, R. W., and Decker-Walters, D. S. 1997. Page 226 in: Cucurbits. $\mathrm{CAB}$ International, NY.

Rostowzew, S. J. 1903. Beiträge zur Kenntnis der Peronosporeen. Flora 92.

Runge, F., Choi, Y. J., and Thines, M. 2011. Phylogenetic investigations in the genus Pseudoperonospora reveal overlooked species and cryptic diversity in the P. cubensis species cluster. Eur. J. Plant Pathol. 129:135-146.

Runge, F., and Thines, M. 2009. A potential perennial host for Pseudoperonospora cubensis in temperate regions. Eur. J. Plant Pathol. 123:483-486.

Savory, E. A., Adhikari, B. N., Hamilton, J. P., Vaillancourt, B., Buell, C. R., and Day, B. 2012a. mRNA-Seq analysis of the Pseudoperonospora cubensis transcriptome during cucumber (Cucumis sativus L.) infection. PLoS One 7:e35796.

Savory, E. A., Granke, L. L., Quesada-Ocampo, L. M., Varbanova, M., Hausbeck, M. K., and Day, B. 2011. The cucurbit downy mildew pathogen Pseudoperonospora cubensis. Mol. Plant Pathol. 12:217-226.

Savory, E. A., Zou, C., Adhikari, B. N., Hamilton, J. P., Buell, C. R., Shiu, S. H., and Day, B. 2012b. Alternative splicing of a multi-drug transporter from Pseudoperonospora cubensis generates an RXLR effector protein that elicits a rapid cell death. PLoS ONE 7(4):e34701.

Scherf, A., Schuster, C., Marx, P., Gärber, U., Konstantinidou-Doltsinis, S., and Schmitt, A. 2010. Control of downy mildew (Pseudoperonospora cubensis) of greenhouse grown cucumbers with alternative biological agents. Commun. Agric. Appl. Biol. Sci. 75:541-554. 
Shattock, R. C. 1986. Inheritance of metalaxyl resistance in the potato late blight fungus. In: Proc. Brighton Crop Prot. Conf., Vol. 2, British Crop Prot. Council, Thornton Heath, Surrey, UK.

Shattock, R. C. 1988. Studies on inheritance of resistance to metalaxyl in Phytophthora infestans. Plant Pathol. 37:4-11.

Shaw, D. S., and Shattock, R. C. 1991. Genetics of Phytophthora infestans: The Mendelian approach. Phytophthora. J. A. Lucas, R. C. Shattock, D. S. Shaw, and L. R. Cooke, eds. Cambridge University Press, Cambridge, UK.

Shetty, N. V., and Wehner, T. C. 2002. Screening the cucumber germplasm collection for fruit yield and quality. Crop Sci. 42:2174-2183.

Shimizu, S., Kanazawa, K., Kato, A., Yokota, Y., and Koyama, T. 1963. Studies on the breeding of cucumber for the resistance to downy mildew and other fruit characters. Engei Shikenjo ho koku. 2:65-81. (in Japanese)

Sierotzki, H., Blum, M., Olaya, G., Waldner-Zulauf, M., Wullschleger, J., Cohen, Y., and Gisi, U. 2011. Sensitivity to CAA fungicides and frequency of mutations in cellulose synthase (CesA3) gene of oomycete pathogen populations. In: Modern Fungicides and Antifungal Compounds VI. H. W. Dehne, H. B. Deising, U. Gisi, K. H. Kuck, P. E. Russell, and H. Lyr, eds. Proc. 16th Intl. Reinhardsbrunn Symp., DPG Selbstverlag, Braunschweig, Germany.

Sierotzki, H., Kraus, N., Assemat, P., Stanger, C., Cleere, S., Windass, J., and Gisi, U. 2005. Evolution of resistance to QoI fungicides in Plasmopara viticola populations in Europe. In: Modern Fungicides and Antifungal Compounds IV. H. W. Dehne, U. Gisi, K. H. Kuck, P. E. Russell, and H. Lyr, eds. Proc. 14th Intl. Reinhardsbrunn Symp., BCPC, Alton, UK.

Sierotzki, H., Parisi, S., Steinfeld, U., Tenzer, I., Poirey, S., and Gisi, U. 2000a. Mode of resistance to respiration inhibitors at the cytochrome bc1 enzyme complex of Mycosphaerella fijiensis field isolates. Pest Manag. Sci. 56: 833-841

Sierotzki, H., Wullschleger, J., and Gisi, U. 2000b. Point-mutation in cytochrome b gene conferring resistance to strobilurin fungicides in Erysiphe graminis f. sp. tritici field isolates. Pestic. Biochem. Physiol. 68:107-112.

Sitterly, W. R. 1973. Cucurbits. Breeding plants for disease resistance, concepts and applications. R. R. Nelson, ed. Pennsylvania State University Press, University Park.

Skalický, V. 1961. Plíseň okurková - Peronoplasmopara cubensis (Berk. et Curt.) Clinton. Zemědělská fytopatologie, Díl III, Choroby zeleniny. J. Benada and J. Špaček, eds. Czech Academy of Agricultural Sciences.

Smolák, J. 1927. Information Service. Second Annual Report of Phytopathology Station, Mělník, for the year 1925-1926: 90-95. (in Czech) Rev. Appl. Mycol. 6:213. (in English)

St. Amand, P. C., and Wehner, T. C. 1991. Crop loss to 14 diseases in cucumber in North Carolina for 1983 to 1988. Cucurbit Genet. Coop. Rpt. 14:15-17.

Staub, T., and Sozzi, D. 1981. Résistance au métalaxyl en pratique et les consequences pour son utilisation. Phytiat. Phytopharm. 30:283-291. (in French)

Sundheim, L., and Hodnebrog, T. 1987. Agurk bladskimmel erfunnen i Norge. Gartneryrket 30:701.

Sweigard, J. A., Andreassi, J., Pember, S., Gutteridge, S., Pasteris, R., Hanagan, M. A., and Caroll, A. C. Sopa, J., and Nesnow, D. 2014. Discovery of the target site of oxathiapiprolin (DuPont Zorvec disease control). 13th IUPAC Congress of Pesticide Chemistry, San Francisco, abstract Agro 911.

Tahvonen, R. 1985. Downy mildew of cucurbits found for the first time in Finland. Vaxtskyddsnotiser 49:42-44.

Takeda, T., Kawagoe, Y., Uchida, K., Fuji, M., and Amano, T. 1999. The appearance of resistant isolates to strobilurins. Ann. Phytopathol. Soc. Jpn. 65:655. (Japanese abstract)

Tatlioglu, T. 1993. Cucumbers. Genetic Improvement of Vegetable Crops. G. Kalloo, and B. O. Bergh, eds. Pergamon Press, New South Wales, Australia.

Thomas, A., Carbone, I., and Ojiambo, P. S. 2013. Occurrence of the A2 mating type of Pseudoperonospora cubensis in the United States. (Abstr.) Phytopathology 103:S2.145.

Thomas, A., Carbone, I., and Ojiambo, P. S. 2014. Comparative genomic analysis of Pseudoperonospora cubensis to elucidate the genetic basis of host specialization. (Abstr.) Phytopathology 104:S3.118.

Thomas, C. E. 1996. Downy mildew. Pages 25-27 in: Compendium of $\mathrm{Cu}-$ curbit Diseases. American Phytopathological Society, St. Paul, MN

Thomas, C. E., Inaba, T., and Cohen, Y. 1987. Physiological specialization in Pseudoperonospora cubensis. Phytopathology 77:1621-1624.

Thornton, A. C., Holmes, G. J., and Adams, M. L. 2005. Evaluation of fungicides for control of downy mildew of cucumber, 2004. Fungic. Nematic. Tests 60:V059.
Tian, M., Win, J., Savory, E., Burkhardt, A., Held, M., Brandizzi, F., and Day, B. 2011. 454 Genome sequencing of Pseudoperonospora cubensis reveals effector proteins with a QXLR translocation motif. Mol. Plant-Microbe Interact. 24:543-53.

Van der Plank, J. E. 1968. Disease Resistance in Plants. Academic Press, New York.

Van Haltern, F. 1933. Spraying cantaloupes for the control of downy mildew and other diseases. Geo. Agric. Exp. Stn. Bull. 175:1-53.

Van Vliet, G. J. A., and Meysing, W. D. 1974. Inheritance of resistance to Pseudoperonospora cubensis Rost. in cucumber (Cucumis sativus L.). Euphytica 23:251-255.

Van Vliet, G. J. A., and Meysing, W. D. 1977. Relation in the inheritance of resistance to Pseudoperonospora cubensis Rost. and Sphaerotheca fuliginea Poll. in cucumber (Cucumis sativus L.). Euphytica 26:793-796.

Van den Langenberg, K. 2014. Studies on downy mildew resistance in cucumber (Cucumis sativus L.). Ph.D. Thesis, North Carolina State University, Raleigh.

Voglmayr, H., Riethmuller, A., Goker, M., Weiss, M., and Oberwinkler, F. 2004. Phylogenetic relationships of Plasmopara, Bremia and other genera of downy mildew pathogens with pyriform haustoria based on Bayesian analysis of partial LSU rDNA sequence data. Mycol. Res. 108:1011-1024.

Wallace, E., Adams, M., Ivors, K., Ojiambo, P. S., and Quesada-Ocampo, L. M. 2014. First report of Pseudoperonospora cubensis causing downy mildew on Momordica balsamina and M. charantia in North Carolina. Plant Dis. 98:1279.

Wallace, E., and Quesada-Ocampo, L. M. 2014. In silico identification and analysis of microsatellite location and frequency in downy mildew transcriptomes. Phytopathology 104:499.

Wang, Y., Van den Langenberg, K., Wehner, T. C., and Weng, Y. 2014. QTLs for downy mildew resistance and their association with LRR-RLK resistance gene analogs in cucumber. Cucurbitaceae 2014:17-20.

Wehner, T. C., and Shetty, N. V. 1997. Downy mildew resistance of the cucumber germplasm collection in North Carolina field tests. Crop Sci. 37: 1331-1340.

Wellings, C. R. 2007. Puccinia strifformis in Australia: A review of the incursion, evolution, and adaptation of stripe rust in the period 1979-2006. Aust. J. Agric. Res. 58:567-575.

Whisson, S. C., Boevink, P. C., Moleleki, L., Avrova, A. O., Morales, J. G., Gilroy, E. M., Armstrong, M. R., Grouffard, S., Van West, P., Chapman, S., Hein, I., Toth, I. K., Pritchard, L., and Birch, P. R. J. 2007. A translocation signal for delivery of oomycete effector proteins into host plant cells. Nature 450:115-118.

Whisson, S. C., Fonné-Pfister, R., and Csukai, M. 2011. Molecular approaches to elucidate pathways and sites of fungicide resistance in Oomycetes. In: Modern Fungicides and Antifungal Compounds VI. H. W. Dehne, H. B. Deising, U. Gisi, K. H. Kuck, P. E. Russell, and H. Lyr, eds. Proc. 16th Intl. Reinhardsbrunn Symp., DPG Selbstverlag, Braunschweig, Germany.

Withers, S., Gongora-Castillo, E., Bowman, M. J., Childs, K. L., Gent, D., Ojiambo, P., and Quesada-Ocampo, L. M. 2014. Developing genomic resources for species-specific molecular diagnostics of cucurbit downy mildew. Phytopathology 104:397.

Yoshioka, Y., Sakata, Y., Sugiyama, M., and Fukino, N. 2014. Identification of quantitative trait loci for downy mildew resistance in cucumber (Cucumis sativus L.). Euphytica 198:265-276.

Zacha, V., Janýška, A., and Holman, B. 1985. Epifytócia plesne uhorkovej (Pseudoperonospora cubensis (Berk. et Curt.) Rost.) v ČSSR v roku 1984. Sborník ÚVTIZ-Ochrana Rostlin 21:226.

Zhang, S. P., Liu, M. M., Miao, H., Zhang, S. Q., Yang, Y. H., Xie, B. Y., Todd, C. W., and Gu, X. F. 2013. Chromosomal mapping and QTL analysis of resistance to downy mildew in Cucumis sativus. Plant Dis. 97:245-251.

Zhang, S. Q., Gu, X. F., Zhang, S. P., and Zou, Z. R. 2007. Genetic analysis of downy mildew resistance in cucumber. Acta Bot. Boreali-Occidentalia Sin. 27:2416-2420.

Zhang, Y. J., Pu, Z. J., Qin, Z. W., Zhou, X. Y., Liu, D., Dai, L. T., and Wang, W. B. 2012. A study on the overwintering of cucumber downy mildew oospores in China. J. Phytopathol. 160:469-474.

Zhu, S. S., Liu, X. L., Wang, Y., Wu, X. H., Liu, P. F., Li, J. Q., Yuan, S. K., and Si, N. G. 2007. Resistance of Pseudoperonospora cubensis to flumorph on cucumber in plastic houses. Plant Pathol. 56:967-975.

Zimmermann, A. 1909. Verzeichnis der Pilze aus der Umgebung von Eisgrub. I. Verh. Naturforschenden Vereines Brunn 47:60-118.

Zohary, D., Hopf, M., and Weiss, E. 2012. Domestication of Plants in the Old World. Oxford University Press, Oxford, UK. 